\title{
LIMITED PARTNERSHIPS IN THE ALBERTA OIL AND GAS INDUSTRY
}

\author{
R. G. POWERS*
}

Limited partnerships, as a financing vehicle in the oil and gas industry, are gaining popularity. This paper reviews the law relating to limited partnerships in Alberta, emphasizing those problems of particular significance in the formation of such a partnership for participation in the oil and gas business. Relevant provincial and federal statutory provisions are considered, and a draft Partnership Agreement is set out. The author also highlights the distinctions between the limited partnership, joint venture, and operating agreement.

\section{INTRODUCTION}

In Canada, until recently, the limited partnership as a vehicle for the conduct of oil and natural gas exploitation enjoyed relatively little popularity, both among the operators of oil and gas properties and potential sources of financing for such operations. This may be due to the lack of uniformity in limited partnership legislation across Canada, the lack of understanding of the concept or the notoriety of some United States ventures.

Recently, however, the oil and gas industry, investors and brokerage houses have shown increasing interest in drilling funds, including limited partnerships, as vehicles for financing and carrying out operations. Possibly this is the result of amendments to the Income Tax Act since 1972, favouring the oil and gas type of investment and restricting or eliminating other types of investments. Additionally, there has been a decline in the attractiveness of the equity markets and equity financing, particularly in regard to junior oil stocks.

But the limited partnership has advantages both to investors who are not sophisticated in matters of oil and gas industry operations, and to the operator. One advantage to the operator is the preservation of his unfettered conduct of the business. As for the investor, he is placed in the position of an owner of oil and gas property for income tax purposes but at the same time enjoys the benefits of the corporate concept of limited liability.

This paper will be restricted to a consideration of the limited partnership in Alberta.

Unless expressly stated, references to sections of statutes may be paraphrased and the reader should refer to the section in question.

\section{AN ABRIDGED REVIEW OF PARTNERSHIP LAW WITH COMMENTS}

\section{Background}

Limited partnerships in common law jurisdictions are creatures of statute. Although the concept appears to have existed in Europe since the Middle Ages, ${ }^{1}$ limited partnerships were not recognized in England as a specific form until the Limited Partnerships Act of 1907. The limited

- Barrister and Solicitor, Howard, Dixon, Mackie and Foroyth, Calgary, Alberta.

1. Scamell, Lindley on Partnerahip, 783 (1971). 
partnership was first recognized in Western Canada in $1899,{ }^{2}$ and came into force in its present form on June 1, 1968.

The Partnership Act, R.S.A. 1970, c. 271 (hereinafter referred to as "the Act"), Part 2, provides that a limited partnership has two classes of partners: general and limited. Section 55 provides:

8. 55 A general partner in a limited partnership has all the rights and powers and is subject to all the restrictions and liabilities of a partner in a partnership without limited partners. ... .

In view of Section 55, consideration must be given to the common law principles of partnerships as well as to the provisions of the Act.

The position of the limited partners will be dealt with later in this paper, under the heading "Rights and Liabilities of Limited Partners".

2. Equity, the Common Law and Part I of the Partnership Act

Section 55 of the Act treats general partners as if they were partners in an ordinary partnership. Section 80 of the Act provides that the rules of equity and common law applicable to partnerships continue in force except where inconsistent with the Act.

If the limited partnership is intended to have only one general partner, the complexities of an ordinary partnership in relation to day-to-day operations, policy decisions and accounting as between the general partners can be eliminated. However, a financing agreement may require that there be more than one general partner. Therefore, a knowledge of partnership law, as it applies to ordinary partnerships, is essential. For the purposes of this paper, only a brief review of equity and common law rules applying to partners and partnerships (with reference to items specifically dealt with by the Act) will be made.

Some general principles which should be remembered in considering the position of the general partners are:

1. Each partner is an agent of the firm and of his other partners for the purpose of the business of the partnership.

The acts of each partner in carrying on, in the usual way of business, the type of business carried on by the firm of which he is a member, bind the firm and his partners, unless

(a) the partner 80 acting has in fact no authority to act for the firm in the particular matter, and

(b) the person with whom the partner is dealing knows that the partner has no authority, or does not know or believe him to be a partner.

Notes:

(i) This is section 7 of the Act.

(ii) The authority to bind the partnership may be express or implied. A formal provision in an agreement is unnecessary if what is done is done in the ordinary course of business. ${ }^{3}$

(iii) An act of a partner for and on behalf of the partnership, not in the ordinary course of business of the partnership and not otherwise authorized or ratified by the partners, will not be binding upon the partnership. ${ }^{4}$

2. O.N.W.T., 1899, c. 7.

3. Scamell, Lindley on Partnerohip, 160 (1971).

4. Id. 
(iv) This item is subject to section 10 of the Act which deals with agreed limitations on partners' powers to bind the partnership, but is distinguishable from the position of a limited partner.

2. Silent or dormant partners share the same liabilities as active partners vis-a-vis outsiders to the partnership. ${ }^{5}$

Notes:

(i) The active partner(s) may in fact indemnify the dormant partner. This would not, however, affect the dormant partner's liabilities to outsiders.

3. Accounts rendered by one partner relative to partnership transactions are equivalent to an account rendered by the partnership. ${ }^{6}$

4. Payment of a debt to one partner constitutes payment to all; ; but one partner does not have the power to compromise or settle a debt by forgiving the debt or by accepting payment in some manner other than the usual means.

5. A partner has the implied authority to hire servants and agents to conduct the business of the partnership and to discharge them, although he may not have the power to discharge them against the will of his co-partners. ${ }^{8}$

6. One partner cannot, without special authority, bind the firm by submission to arbitration.

\section{Notes:}

(i) Submission to arbitration may not be regarded as the ordinary course of business of the partnership.

7. A partner has the authority to pledge the credit of the partnership for purposes connected with its ordinary course of business and outside the ordinary course of business if specifically authorized.

Notes:

(i) See section 9 of the Act which places this proposition in the negative.

(ii) Lindley suggests that there is an implied power to borrow only where the business carried on in its usual way cannot be carried on without it.9

(iii) The granting of security will follow from the provisions of section 9. However, as a practical matter, a limited partnership may be restricted in the kinds of enforceable security it can give, with respect to registration of mortgages and debentures against Crown lands.

(iv) Section 9 would, however, likely preclude the granting of collateral security guaranteeing the debts of others, unless such authority were specifically given in the partnership agreement.

(v) In dealing with limited partners as creditors otherwise than in respect of their contributions, see section 59 of the Act. 
8. Each partner is jointly liable with the other partners for debts and obligations of the partnership incurred while he is a partner.

Notes:

(i) See section 11(1) of the Act.

9. The partnership will be liable to outsiders to the partnership for wrongful acts of commission or omission of or by a partner acting within the ordinary course of business of the partnership or with the authority of the other partners.

Notes:

(i) See section 12 of the Act which does not restrict the personal liability of the partner.

10. The partnership is liable to a party suffering damages where:

(a) a partner acting within the scope of his authority receives money or property and misapplies it, or

(b) the partnership in the course of its business receives money or property and the same is misapplied by one or more of the partners while it is in the custody of the partnership.

Notes:

(i) See section 13 of the Act.

11. Each partner is jointly and severally liable with his co-partners under items 9 and 10 above for any liabilities of the partnership incurred while he is a partner.

Note8:

(i) See section 14 of the Act.

12. A partner will be liable as such to creditors of the partnership for those matters arising after the date of his admission into the partnership. A person who retires from the partnership continues to be liable for debts or obligations of the partnership created before his retirement.

Notes:

(i) See section 19 of the Act.

(ii) This item is an important consideration in timing admittance of partners as well as withdrawal from the partnership.

13. In the absence of any agreement to the contrary expressed or implied, the following rules govern the rights and duties of partners, inter se:

(a) all partners are entitled to share equally in the capital and profits of the business and shall contribute equally toward the losses (whether of capital or otherwise) sustained by the firm;

(b) the firm shall indemnify each partner in respect of payments made and personal liabilities incurred by him

(i) in the ordinary and proper conduct of the business of the firm, or

(ii) in or about anything necessarily done for the preservation of the business or property of the firm;

(c) a partner who, for the purpose of the partnership, makes a payment or advance beyond the amount of capital that he has agreed to subscribe, is entitled to interest from the date of the payment or advance; 
(d) a partner is not entitled to interest on the capital subscribed by him before the ascertainment of profits;

(e) each partner may take part in the management of the partnership business;

(f) no partner is entitled to remuneration for acting in the partnership business;

(g) no person may be introduced into the firm as a partner without the consent of all existing partners;

(h) a difference arising as to ordinary matters connected with the partnership business may be decided by a majority of the partners;

(i) no change may be made in the nature of the partnership business without the consent of all existing partners;

(j) the partnership books are to be kept at the place of business of the partnership, or the principal place of business if there is more than one, and each partner may have access to and inspect and copy any of the books.

Notes:

(i) See section 27 of the Act.

(ii) Item (g) is modified by section 55(e) with respect to the admission of general partners and section 55(f) with respect to the admission of limited partners in a limited partnership.

\section{Part 2 of the Partnership Act}

With respect to limited partnerships, Parts 1 and 3 of the Act are subject to the provisions of Part 2 by virtue of section 48. Therefore, the position of the general partners and limited partners, being broadly regarded together as "partners", will be more specifically qualified and defined by Part 2.

\section{(A) The Partners}

The underlying distinction between an ordinary partnership and a limited partnership is found in section 50(2) of the Act, which provides that there must be at least one general partner and at least one limited partner to create (see section $51(1)$ ) and maintain (see section 68(1)(b)) a limited partnership.

\section{(B) The Certificate}

Section $51(1)$ of the Act requires that a Certificate substantially complying with subsection (2) be filed and recorded in the Central Registry. Presumably then, the certificate could contain information in addition to that required by Part 2 so long as it was not in contravention of the law. For example, it might contain reference to any matter dealt with under section 27 , a limitation on the power of general partners to conduct the business of the partnership (if there were more than one general partner) as contemplated by section 10 , or other matters as between the partners.

The certificate shall be signed by all the partners desiring to form the limited partnership and shall contain the following:

1. the firm name under which the limited partnership is to be conducted; 
2. the character of the business;

3. the name and place of residence of each partner, general and limited partners being respectively designated;

4. the term for which the limited partnership is to exist;

5. the amount of cash and the nature and fair value of other property, if any, contributed by each limited partner;

6. the amount of additional contributions, if any, agreed to be made by each limited partner and the times or events which trigger an additional contribution;

7. the time, if agreed upon, when the contribution of each limited partner is to be returned;

8. the share of the profits or other compensation by way of income which each limited partner is entitled to by reason of his contribution;

9. the right, if given, of a limited partner to substitute an assignee as contributor in his place, and the terms and conditions of the substitution;

10. the right, if given, of the partners to admit additional limited partners;

11. the priority, if given, of one or more of the limited partners to a return of contributions or to compensation by way of income, and the nature of the priority;

12. the right, if given, of the remaining general partner or partners to continue the business on the death, retirement or mental incompetence of a general partner; and

13. the right, if given, of a limited partner to demand and receive property other than cash in return for his contribution.

However, there are other provisions in Part 2 which must be considered in addition to those set out in section $51(2)$.

1. Section 55(f)-The general partner may not admit additional limited partners unless the certificate so provides.

Notes:

(i) If this power is specifically given to the general partner it must be so stated.

2. Section 60(2)-Any priorities as between limited partners in respect of:

(a) return of contributions,

(b) compensation by way of income, or

(c) any other matter;

must be stated in the certificate "and in the absence of a statement all limited partners, subject to subsection (1), stand upon equal footing".

Notes:

(i) Section 60(1) is subject to this subsection and provides that the limited partners share in capital and income on their contributions in proportion to their respective claims.

(ii) The effect of subsection (2) would therefore appear to be that if the existence and nature of an agreement creating the priorities is not stated in the certificate, then it is deemed not to exist. 
3. Section 61(2)(b)-If a limited partner has the right to demand return of his contribution, the time when the demand may be made must be stated in the certificate.

Notes:

(i) Section $58(1)$ (b) provides that a limited partner has the right to have his contribution returned.

4. Section 61(2)(c)-If no time is specified in the certificate for either the return of the contribution or for the dissolution of the partnership, a limited partner may demand return of his contribution by giving six months notice to his co-partners.

5. Section 61(3)(a)-Notwithstanding the form a limited partner's contribution originally took, unless otherwise provided in the certificate, the limited partner may only demand and receive return of his capital in cash.

Notes:

(i) Section 61(3)(b), however, provides that a return other than cash may be made if the consent of all the partners is obtained.

6. Section 72-The order of payment of obligations and return of capital on dissolution is set forth, subject to any variation thereof as to the priorities between the limited partners set forth in the certificate.

Notes:

(i) See section 60(2) and discussion above on the matter of priorities among the limited partners.

7. Section 73-A false statement contained in a certificate which was relied upon by any person and resulted in a loss to him creates liability in any partner who signed the certificate knowing it to be false or who failed to correct a false statement after he became aware of the false statement and could have corrected the statement before the person had relied upon it.

Notes:

(i) Qualifications on the liabilities of limited partners and their substitutes will be discussed below.

8. Section 78-A limited partnership formed prior to June 1, 1968 may be transformed into a limited partnership under Part 2 of the Act by filing a certificate in accordance with section 78(1). If no certificate is filed, such a limited partnership will be governed by sections 48 to 66 of c. 230, R.S.A. 1955.

Notes:

(i) In acting for a prospective investor in a limited partnership it would be worthwhile establishing the date of formation of the limited partnership.

Since there is no provision for filing the limited partnership agreement as a public document, any statements contained in the certificate would likely be strictly construed. Failure to adequately describe any matter required to be disclosed in the certificate pursuant to section 51(2) or in any Notice to Amend a Certificate pursuant to section 69(1) (discussed infra) may give rise to civil liability pursuant to section 72 . 
(C) Amendment or Cancellation of the Certificate

Section 69(1) provides that the certificate shall be amended when:

1. there is a change in the name of the limited partnership or in the amount or character of the contribution of any limited partner not provided for in the certificate;

2. a person is substituted as a limited partner;

3. a person is added as a limited partner;

4. a person is added as a general partner;

5. a general partner retires, dies or becomes mentally incompetent, and the business is continued pursuant to section 66;

6. there is a change in the character of the business of the limited partnership;

7. a false or erroneous statement is discovered in the certificate;

8. there is a change in the time (as stated in the certificate) for the dissolution of the limited partnership or for the return of a contribution;

9. a time is fixed for the dissolution of the limited partnership or for the return of a contribution, no time having been specified in the certificate; or

10. the partners desire to make a change in any other statement in the certificate in order to make the certificate accurately represent the agreement between them.

This is done by filing with the Registrar of the Central Registry a Notice to Amend a Certificate pursuant to section 71 .

The Notice to Amend a Certificate shall:

1. set forth the change in or addition to the certificate which is desired:

2. be signed by all partners (limited and general); and

3. where limited or general partners are being added or a limited partner substituted, be signed by the new or substituted partners and assigning limited partner.

Notes:

(i) See section 69(2) and (3).

(ii) The Notice to Amend a Certificate should clearly identify the limited partnership by name, set forth the original registration number and date of registration, and refer to the dates and registration numbers of previous amendments.

By virtue of section 68 , the certificate shall be cancelled when:

1. the limited partnership is dissolved, or

2. all the limited partners cease to be limited partners.

This is done by filing a Notice to Cancel a Certificate with the Registrar of the Central Registry pursuant to section 71 ; section 68(2) requires that all the parties sign the Notice. The Notice to Cancel a Certificate should state the reason for cancellation and should contain the additional information referred to above.

The cancellation of the certificate does not of itself have the effect of dissolving the partnership unless so provided by agreement); it only removes the status of a limited partnership and creates an ordinary 
partnership among the remaining partners. Section $68(1)(a)$ provides that the certificate will be cancelled if the limited partnership is dissolved.

In fact, there is no express provision in the Act which states that a limited partnership ceases to exist as such when the certificate is cancelled, although it would seem that such was the intention. Furthermore, the date upon which the loss of limited partnership status would be effective, being the date of registration of the Notice to Cancel a Certificate, could be delayed by delaying the date upon which a Notice to Cancel a Certificate is delivered to the Central Registry as required by section 71(a).

Section $70(1)$ permits a person desiring cancellation of a certificate to bring an action before the Supreme Court of Alberta when a person who must sign a Notice to Cancel a Certificate refuses to do so. The Court may direct "the registrar of the Central Registry to record the cancellation or amendment of the certificate as set forth in the order." But section 71 provides that in such a case the certificate is cancelled upon the filing of a certified copy of the order. These comments apply as well in respect to amendments required pursuant to section 69.

The timing of the change of status of a limited partnership can be important:

1. At the time of the return of a limited partner's contributions pursuant to section $61(1)$; or

2. At the time of conversion from a limited to an ordinary partnership.

The first case can be seen to work against the limited partner. The second case could work against the general partner if the effect was to postpone the date of a limited partner becoming a partner in an ordinary partnership (into which the limited partnership was being converted) to a date subsequent to the creation of a liability (see section 19).

\section{(D) Rights and Liabilities of Limited Partners}

\section{Liabilities}

The liability of a limited partner is limited to the amount of his contribution to the limited partnership.

1. Section 56-Subject to Part 2, a limited partner is not liable for the obligations of the limited partnership except in respect of the amount of property he contributes or agrees to contribute to the capital of the limited partnership.

2. Section 63-A limited partner does not become liable as a general partner unless, in addition to exercising his rights and powers as a limited partner, he takes part in the control of the business.

This must be qualified, however, as follows:

1. Section 53(2)-A limited partner whose surname appears in the firm name is liable as a general partner to any creditor of the limited partnership who has extended credit to the limited partnership without the actual knowledge that the limited partner was not a general partner.

Notes:

(i) This is qualified by subsection (1) which permits the use of the surname if the limited partner is also a general partner. 
(ii) Section $52(1)$ permits a person to be both a limited and general partner at the same time, but preserves the distinction as to rights in each capacity by section $52(2)$.

2. Section 62(1)-A limited partner is liable to the limited partnership for:

(a) any difference between the actual amount of his contribution: and the amount stated in the certificate; and

(b) any unpaid contribution he agreed in the certificate to make in the future at the time and on conditions, if any, stated in the certificate.

3. Section 62(2)-A limited partner is made a trustee for the benefit of the limited partnership in respect of:

(a) specific property stated in the certificate as contributed by him but in fact not contributed or wrongfully returned to him, and

(b) money or other property wrongfully paid or conveyed to him on account of his contribution.

4. Section 62(5)-A limited partner who has rightfully received the return of all or any part of the capital of his contribution remains liable to the partnership for all or any part of his return, plus interest, necessary to discharge the partnership's liabilities to creditors who extended credit or whose claims otherwise arose before the return.

5. Section 63-So long as a limited partner does not take part in the control of the partnership business he will preserve his limited liability.

6. Section 65(6)-A substituted limited partner assumes all of the rights and liabilities of the assignor of the limited partnership interest, except those liabilities of which he was ignorant at the time he became a limited partner and which could not be ascertained from the certificate.

Notes:

(i) This section raises the question of the duty on the investor to inform himself as to liabilities attaching to the interest. The section seems to limit him to examining the certificate at the time he is substituted as a limited partner. However, if he had knowledge of a liability attaching to the interest although not appearing on the certificate, it would not seem likely that he could claim the protection of this section in equity. As a matter of precaution, an assignee of a limited partnership interest would be well advised to obtain a written representation from the assignor to the effect that:

A. the interest has not been assigned, pledged or otherwise encumbered;

B. there is no liability attaching to the interest nor any other matter which is required to be disclosed in the certificate other than those disclosed at the date of the representations; and

C. the assignor is not aware of any matters which may arise in the future that would be required to be disclosed in the certificate. 
7. Section 67-The estate of a deceased limited partner is liable for all the liabilities of the deceased limited partner in respect of the limited partnership.

8. Section 73-A limited partner is liable for losses suffered by third parties as a result of false statements in the certificate.

Notes:

(i) See discussion supra at page 159.

9. Section 74-A person contributing capital to a business conducted by a person or partnership erroneously believing that he has become a limited partner in a limited partnership

(a) is not, by reason only of his exercising the rights of a limited partner, a general partner with the person or in the partnership carrying on the business, and

(b) is not bound by the obligations of the person or partnership carrying on the business, if, upon ascertaining the fact that he is not a limited partner, he promptly renounces his interest in the profits or other compensation by way of income from the business.

Notes:

(i) This section also raises the question how far the investor must go to ascertain the nature of the interest being acquired. Since the requirements of the Act are quite clear as to how a limited partnership is formed, and if one still accepts the doctrine of caveat emptor, the question arises whether or not this section would be limited to cases of fraud or misrepresentation.

(ii) This section requires that the investor renounce his profits but does not give him much assistance in recovering his contribution.

Rights

The rights of a limited partner are, essentially, restricted to enabling him to inform himself as to the application of his investment, to share in partnership profits and to obtain return of his contribution.

These rights may be summarized as follows:

1. Section 54(1)-A limited partner may contribute cash and other property to the limited partnership, but not services.

Notes:

(i) The latter qualification follows from section 63.

2. Section 57-A limited partner has the same right as has a general partner.

(a) to inspect and make copies or or take extracts from the limited partnership books at all times,

(b) to be given, on demand, true and full information of all things affecting the limited partnership, and to be given a formal account of partnership affairs whenever circumstances render it just and reasonable, and

(c) to obtain dissolution and winding up of the limited partnership by court order.

3. Section 58(1)-A limited partner has, subject to the Act, the right:

(a) to a share of the profits or other compensation by way of 
income, and

(b) to have his contribution to the limited partnership returned.

Notes:

(i) Paragraph (b) does not contemplate a partial return of contribution. However, section 61(1) may imply this by use of the words ". . . any part of his contribution ...", although the latter provision would be equally consistent with the concept that section $61(1)$ is subject to section 72 and applies both before and after dissolution. In that case, a limited partner, on dissolution, may only receive back a part of his contribution after payment of prior liabilities.

4. Section 58(2)-A limited partner may receive from the limited partnership the share of the profits or the compensation by way of income stipulated for in the certificate if, after payment thereof is made (whether from the property of the limited partnership or that of the general partner) the limited partnership assets exceed all the limited partnership liabilities, excepting liabilities to limited partners on account of their contributions and liabilities to general partners.

Notes:

(i) This section requires that the limited partnership's assets exceed the limited partnership's liabilities to creditors (other than in respect of the contributions of both limited and general partners) if a share of profits or compensation by way of income be distributed either by payment from the general partner(s) or the limited partnership.

(ii) The wording of this subsection seems to suggest that the limited partners share in income before the general partner does:

". . excepting liabilities to limited partners on account of their contributions and to general partners."

This should be distinguished from section 72 which is operative on dissolution.

165.)

(See discussion in respect of section 61(1), infra, at page

(iii) Generally speaking, however, the word "capital" is used in connection with the contributions of ordinary partners and the word "contribution" in connection with limited partners. It is therefore not clear whether the legislature intended a different construction as between this section and section $61(1)$ or merely reversed the order of the wording unintentionally.

5. Section 59-A limited partner may loan money to and transact business with the limited partnership and may share pro rata with other general creditors of the limited partnership's assets in respect of his claims, unless he is also a general partner. However, he may not:

(a) take security on the limited partnership's assets for debts due him, or

(b) receive from the general partner or the limited partnership any payment, conveyance or release from liability if at the time the 
partnership assets are insufficient to meet liabilities due to outside creditors.

Notes:

(i) A person dealing with the limited partnership in which he is a limited partner will be treated as an unsecured creditor and will therefore rank junior to arm's length creditors who take security on the partnership assets, such as section 82 security under the Bank Act (Canada), assignments of book debts, chattel mortgages, mortgages, etc.

(ii) The power to compromise or settle a debt with a limited partner claiming as a general partner is likewise restricted.

6. Section 60(1)-Subject to section 60(2), limited partners share in distributions of capital and income in proportion to their claims.

Notes:

(i) Presumably "claims" is a reference to the limited partners' contribution or agreed share of profits.

(ii) Section 60(2) was discussed supra at page 158, and essentially provides for priorities as between limited partners.

(iii) General partners are governed by section 27(a).

7. Section 60(2)-Priorities may be created as between limited partners in respect of return of contribution, compensation by way of income and other matters. But these must be set forth in the certificate.

Notes:

(i) See discussion supra at page 158.

8. Section 61(1)-A limited partner is not entitled to receive from a general partner or out of the limited partnership property any part of his contribution until:

(a) all liabilities of the limited partnership, excepting liabilities to general partners and to limited partners on account of their contributions, have been paid or there remains sufficient limited partnership property to pay them,

(b) the consent of all partners is obtained, unless the return of the contribution may be rightfully demanded under subsection (2), and

(c) the certificate is cancelled or so amended as to set forth the withdrawal or reduction.

Notes:

(i) See sections 58(1)(b) and 69(1)(a).

(ii) See the discussion concerning section 58(2), supra at page 164 , for comparison. This subsection may be read as including in the limited partnership liabilities the share of profits or income due to both limited and general partners in determining whether or not a return of contribution may be made, since clause (a) reads:

“. . . excepting liabilities to general partners and to limited partners on account of their contributions ...."

In other words the reference to the general partner and to 
"contributions" could read as inclusive with the limited partners.

(iii) Unless provision is made in the partnership agreement and recorded in the certificate, the consent of all partners (limited and general) must be obtained for a return of contribution.

(iv) The appropriate Notice as required by sections 68 or 69 as the case may be, must be filed in accordance with section 71 before the distribution may be made. (See also section 62(2).)

9. Section 61(2)-Subject to subsection (1), a limited partner may rightfully demand the return of his contribution:

(a) upon dissolution of the limited partnership,

(b) when the time specified in the certificate for its return has arrived, or

(c) after he has given six months' notice in writing to all other partners, if no time is specified in the certificate either for the return of the contribution or for the dissolution of the limited partnership.

10. Section 61(3)-A limited partner has, irrespective of the nature of his contribution, only the right to demand and receive cash in return therefore, unless:

(a) there is a statement to the contrary in the certificate, or

(b) all partners consent to some other manner of returning the contribution.

11. Section 61(4)-A limited partner is entitled to have the limited partnership dissolved and its affairs wound up where:

(a) he rightfully but unsuccessfully demands the return of his contribution, or

(b) the other liabilities of the limited partnership have not been paid, or the limited partnership property is insufficient for their payment as required by subsection $(1)(a)$ and the limited partner seeking dissolution would otherwise be entitled to the return of his contribution.

12. Section 65(1)-A limited partner's interest is assignable.

Notes:

(i) By virtue of section 54(2) a limited partner's interest in the limited partnership is personal property.

13. Section 65(4)-An assignee may become a substituted limited partner.

(a) if all the members (except the assignor) consent thereto, or

(b) if the assignor, being so authorized by the terms in the certificate, gives the assignee that right.

Notes:

(i) The assignee does not become a substituted limited partner until the certificate is amended (see sections 65(5), 69(1)(b) and 71).

(ii) The assignee does not become a substituted limited partner if the assignor in any manner restricts the assignee's right to become a limited partner. 
(iii) By virtue of section 65(3), an assignee who has not become a substituted limited partner in accordance with section 65(4) has no right to:

A. require information regarding partnership transactions, or

B. inspect the books,

but does have the assignor's rights to share in income and return of contribution.

(iv) When section $65(4)(\mathrm{b})$ is read with section $65(3)$, it will be seen that an assignment of a limited partnership interest as security does not make the assignee a limited partner unless the assignee is specifically stated to assume that role.

14. Section 65(6)-A substituted limited partner has all the rights and powers and is subject to all the restrictions and liabilities of his assignor, except those liabilities of which he was ignorant at the time he became a limited partner and which could not be ascertained from the certificate.

Notes:

(i) See Note (i), supra at page 162.

15. Section 72-In settling accounts after the dissolution of a limited partnership the liabilities of the partnership to creditors, excepting:

(a) to limited partners on account of their contributions, and

(b) to general partners,

shall be paid first and then, subject to any statement in the certificate or to subsequent agreement, in the following order.

1. to limited partners in respect of their share of the profits and other compensation by way of income on their contributions;

2. to limited partners in respect of the capital of their contributions;

3. to general partners other than for capital and profits;

4. to general partners in respect of profits;

5. to general partners in respect of capital.

Notes:

(i) the general partners rank last on a distribution upon dissolution of the partnership, even in respect of sums due them for items other than income and contributions. Moreover, the general partner(s) would appear to be entitled to any appreciation in the value of assets unless the certificate (and agreement) provide otherwise.

16. Section 76-A limited partner, unless he is also a general partner, is not a proper party to proceedings against a limited partnership, except where the object of the proceeding is to enforce a limited partner's right against or liability to the limited partnership.

\section{(E) The General Partner}

In addition to the provisions of equity, the common law and Part 1 of the Act, Part 2 contains certain provisions regarding the general partner which must be borne in mind in considering the position of the general partner vis-a-vis the limited partners. 
1. The general partner is liable to the limited partners in respect of their contributions out of its own property as well as out of the property of the limited partnership.

Notes:

(i) Section 61(1) deals with the limited partner's rights to receive a return of their contribution from a general partner or out of the limited partnership property.

(ii) Section 75(2) provides that a limited partner's interest which has been charged by the court pursuant to section 75(1) may be redeemed with the separate property of the general partner, but may not be redeemed with limited partnership property. By reason of this provision, the general partner should satisfy himself as to the financial position of the proposed limited partners.

If the remedy provided under section 75(2) is exercised, the Act is silent on the general partner's position with respect to recovery from the partnership. Therefore, his action would presumably lie only against the limited partner whose interest was attached. In order to do this, the general partner would have to be subrogated to the rights of the creditor, requiring specific provisions in the partnership agreement.

Section 75(1) permits the court to charge the limited partner's interest with payment of the judgment debt and to "appoint a receiver and make all other orders, directions and inquiries which the circumstances of the case require."

2. The general partner's claims for repayment of debts from the limited partnership income and return of contribution rank junior to all other claims against the partnership.

Notes:

(i) See section 58(2) and discussion, supra, at page 164.

(ii) See section 72 .

Other specific sections in Part 2 relating to the general partner should also be considered.

1. Section 52(1)-A person may be general partner and a limited partner at the same time in the same limited partnership.

2. Section 52(2)-A person who is both general and limited partner in the same limited partnership may exercise all the rights and is subject to all the restrictions and liabilities of a general partner, except in respect of his contribution as a limited partner.

Notes:

(i) If a general partner is also to occupy the position of a limited partner, this should be clearly stated in the certificate to avoid any question of the nature of his contribution as a limited partner.

3. Section 54(3)-Only the general partners shall be shown at the land titles office as owners of any interest in the limited partnership's real property.

Notes:

(i) As a matter of practice, this is also the case with the Department of Energy and Natural Resources (Alberta). It 
may also be the case with other governmental departments, both provincial and federal.

4. Section 55-A general partner in a limited partnership has all the rights and powers and is subject to all the restrictions and liabilities of a partner in a partnership without limited partners except that, without the written consent to or ratification of the specific act by all the limited partners, a general partner has no authority to:

(a) do any act in contravention of the certificate;

(b) do any act which makes it impossible to carry on the ordinary course of business of the limited partnership;

(c) consent to a judgment against the limited partnership;

(d) possess limited partnership property, or assign any rights in specific partnership property, for other than a partnership purpose;

(e) admit a person as a general partner;

(f) admit a person as a limited partner, unless the right to do so is given in the certificate, or

(g) continue the business of the limited partnership on the death, retirement or mental incompetence of a general partner, unless the right to do 80 is given in the certificate.

Notes:

(i) This section speaks of the general partner in the singular. Thus, if there is more than one general partner in the limited partnership, provision should be made as to which general partner has the authority to bring such matters before the limited partners. This will avoid equal but conflicting rights, and reduce the possibility of contentious situations arising. (See section 27(e))

(ii) Notwithstanding the limitation imposed upon the general partner in respect of the admission of additional partners, the admission of additional partners is clearly contemplated and does not have the effect of creating a new partnership by section 64 .

\section{(F) Dissolution}

Dissolution of partnerships is primarily dealt with in sections 35 to 47 and section 91. In addition, sections. 57(c) and 61(4) grant the limited partner the right to obtain dissolution and winding-up of the limited partnership by court order, and $61(2)(a)$ permits him to demand return of his contribution upon the dissolution of the limited partnership. Finally, section 72 governs the settlement of accounts upon dissolution.

1. Section 35(1)-Subject to an agreement between the partner8, a partnership is dissolved:

(a) if entered into for a fixed term, by the expiration of that term,

(b) if entered into for a single adventure or undertaking, by the termination of that adventure or undertaking, or

(c) if entered into for an undefined time, by a partner giving notice to the other partner or partners of his intention to dissolve the partnership.

2. Section $35(2)$-In the case mentioned in subsection (1), clause (c) 
the partnership is dissolved as from the date mentioned in the notice as the date of dissolution, or if no date is mentioned in the notice, then as from the date of communication of the notice.

Notes:

(i) Presumably the right given under section $35(1)(c)$ is restricted to general partners by virtue of section 57(c) which requires a court order.

(ii) A Declaration of Dissolution must be signed and filed with the Central Registry in accordance with section 91 .

(iii) Section $39(2)$ states that the filing of a section 91 declaration and its publication in the Alberta Gazette will provide notice of dissolution to those who had no prior dealings with the partnership. However, direct notice of dissolution would have to be given to persons dealing with the partnership prior to dissolution by virtue of section $39(1)$.

3. Section 36(2)-A partnership may at the option of the other partners be dissolved if a partner permits his share of the partnership property to be charged under this Act for his separate debt.

Notes:

(i) This section would appear to be restricted to the general partner by virtue of section $75(1)$.

4. Section 37-A partnership is dissolved by the happening of an event that makes it unlawful for the business of the firm to be carried on or for the members of the firm to carry on the business in partnership.

5. Section 38(1)-On application by a partner the court may decree a dissolution of the partnership in any of the following cases:

(a) where a partner is shown to the satisfaction of the court to be of permanently unsound mind;

(b) where a partner other than the partner suing becomes in any way, other than through permanent unsoundness of mind, permanently incapable of performing his part of the partnership contract;

(c) where a partner other than the partner suing has been guilty of such conduct as in the opinion of the court, regard being had to the nature of the business, is calculated to affect prejudicially the carrying on of the business;

(d) where a partner other than the partner suing wilfully or persistently commits a breach of the partnership agreement, or otherwise so conducts himself in matters relating to the partnership business that it is not reasonably practicable for the other partner or partners to carry on the business in partnership with him;

(e) where the business of the partnership can only be carried on at a loss;

(f) where circumstances have arisen that in the opinion of the court render it just and equitable that the partnership be dissolved. 
6. Section 38(2)-In a case arising under subsection (1), clause (a) the application may be made:

(a) on behalf of the partner alleged to be of permanently unsound mind by his guardian, next friend or a person having a right to intervene, or

(b) by any other partner.

Notes:

(i) While the writer is unaware of any cases on the point, presumably clauses (a) and (b) would be restricted so as to apply only in respect of the general partners.

(ii) Assuming provisions relating to dissolution which are not inconsistent with Part 2 are available, clauses (c) and (d) could be applied in respect of an offending limited partner as well as a general partner.

(iii) A section 91 Declaration of Dissolution shall be filed and notices given (see Notes (ii) and (iii) to section 35(2), supra, at pages 169 and 170.

7. Section $40-$ On the dissolution of a partnership or retirement of a partner, any partner.

(a) may publicly give notice of the dissolution or retirement, and

(b) may require the other partner or partners to concur for that purpose in all necessary or proper acts, if any, that cannot be done without his or their concurrence.

8. Section 41 -Where a partnership is dissolved the authority of each partner to bind the firm and the other rights and obligations of the partners continue notwithstanding the dissolution, but only to the extent necessary to wind up the affairs of the partnership and to complete transactions begun but unfinished at the time of the dissolution.

\section{Notes:}

(i) This section is subject to Part 2.

9. Section 43-Where a partner has paid a premium to another on entering into a partnership for a fixed term and the partnership is dissolved before the expiration of that term otherwise than by the death of a partner, the court may order the repayment of the premium, or of such part thereof as it thinks just, having regard to the terms of the partnership contract and to the length of time during which the partnership has been continued, unless:

(a) the dissolution is, in the judgment of the court, wholly or chiefly due to misconduct of the partner who paid the premium, or

(b) the partnership has been dissolved by an agreement containing no provision for a return of the premium or any part thereof.

Notes:

(i) This section would seem to apply as between limited partners, as there is nothing to the contrary in Part 2.

10. Section 44-Where a partnership contract is rescinded on the ground of the fraud or misrepresentation of one of the parties thereto, the party entitled to rescind is, without prejudice to any other right, entitled: 
(a) to a lien on, or right of retention of, the surplus of the partnership assets after satisfying the partnership liabilities, for any sum of money paid by him for the purchase of a share in the partnership and for any capital contributed by him;

(b) to stand in the place of the creditors of the firm for any payment made by him in respect of the partnership liabilities; and

(c) to be indemnified against all the debts and liabilities of the firm by the person guilty of the fraud or making the representation.

Notes:

(i) The Act does not provide for the priority of this section over section 60(2) in the case of a limited partner having a priority pursuant to that section and who was not party to the fraud or misrepresentation excepting, perhaps, to the extent that the rescinding party made any payments on account of the partnership liabilities. However, the Act is not clear as to whether he has a priority in the return of his contribution equal to that of an outside creditor or after outside creditors but ahead of the other limited partners. The writer is not aware of any judicial decisions on this point.

Sections 45,46 and 47 are superseded by the provisions of sections 66 and 72.

\section{General Observations on the Act}

The Act does not appear to contemplate corporate partners in partnership(s), nor partnerships forming partnerships, whether ordinary or limited partnerships. This is evident from the use of the words "he", "his" and "him" in referring to a partner, by provisions relating to the death of a partner, and from sections dealing with the position of a widow, child or legal representative of a deceased partner; furthermore, there are no provisions in respect of the bankruptcy or winding-up of a corporate partner, or the dissolution of a partnership which is in itself a partner in a partnership. Nor does the Act deal with the position of a successor by amalgamation, merger or similar corporate reorganization, a trustee in bankruptcy, receiver, manager, liquidator or other similar appointee.

However, the Act also uses the word "person" which under section 21(1).20 of the Interpretation Act (Alberta) includes corporations. Furthermore, the Act does not prohibit corporations and partnerships from being members of partnerships, nor, conversely, limit the Act to natural persons.

\section{OTHER LEGISLATION TO BE CONSIDERED}

In the formation of a limited partnership, sale of partnership interests, and acquisition of property, the Companies Act.(Alberta), the Securities Act (Alberta), the Public Utilities Board Act (Alberta), the Gas Utilities Act (Alberta) and the Foreign Investment Review Act (Canada) should also be considered. This paper will not attempt to consider all legislation which may affect the conduct of the partnership business. 
1. The Companies Act, R.S.A. 1970, c. 60

Section 50(3) of the Partnership Act specifically excludes limited partnerships from the provisions of section 7 of the Companies Act, thereby permitting in excess of twenty partners without incurring the necessity of incorporation.

Section 13(d) of the Companies Act, however, is not so easily overcome. That section provides:

S. 13 No company shall be formed under this Act, nor has a company power under this Act ...

(d) to execute the office of . . . trustee . . . except as is expressly authorized by this Act. ...

The fact that a company cannot execute the office of a trustee creates very real problems for a corporate general partner since section 22(1) and (2) of the Partnership Act provides:

S. 22(1) Partnership property shall be held and applied by the partners exclusively for the purposes of the partnership and in accordance with the partnership agreement.

(2) Notwithstanding subsection (1), the legal registered estate or interest in land that belongs to the partnership devolves:

(a) according to the nature and tenure thereof, and the general rules of law applicable thereto, and

(b) in trust so far as necessary, for the persons beneficially interested under this section in the land.

Section 54(3) of the Partnership Act provides:

S. 54(3) Only the general partners shall be shown at the land titles office as owners of any interest of the limited partnership in real property.

Section 55(d) of the Partnership Act states:

S. 55 A general partner in a limited partnership has all the rights and powers and is subject to all the restrictions and liabilities of a partner in a partnership without limited partners except that, without the written consent to or ratification of the specific act by all the limited partners, a general partner has no authority to . . .

(d) possess limited partnership property, or assign any rights in specific partnership property, for other than a partnership purpose.

In the case of a corporate limited partner, section 62(2) of the Partnership Act provides:

S. 62(2) A limited partner holds as trustee for the limited partnership:

(a) specific property stated in the certificate as contributed by him, but which has not in fact been contributed or which has been wrongfully returned, and

(b) money or other property wrongfully paid or conveyed to him on account of his contribution.

Clearly, in each of these cases, trusts are created. Equally clearly, the only exceptions to section 13 (d) permitted are those expressly authorized by the Companies Act. The powers given a company under section 20 (1).21 and .22 could by implication authorize the company to carry out the functions of a trustee, but do not expressly authorize it to do so. It will be noted, however, that those items prohibited by section 13 are also items dealt with by specific legislation, either provincial or federal. It may be argued that the intention of section 13 is to prohibit companies incorporated under the Companies Act from engaging in businesses specifically dealt with by other legislation. However, the prohibition in section 13 is an absolute one. To the writer's knowledge, this section has never been interpreted by the courts. However, if the wording of the section were strictly interpreted, it would follow that no company 
incorporated under the Companies Act could act as a general partner. Likewise, the provisions of section 62(2) of the Partnership Act would be put in doubt.

The Canada Corporations Act, R.S.C., c. C-32, section 3(4), prohibits a corporation incorporated under that Act from carrying on the business of, inter alia, a trust company.

2. The Securities Act, R.S.A., 1970, c. 333

The Securities Act defines a "person" as including a partnership. Section 6 provides:

S. 6(1) No person or company shall

(a) trade in a security unless such person or company is registered as a dealer, or as a salesman of a registered dealer.

The definition of a "security" includes:

S. 2(1).27(i) any document, instrument or writing commonly known as a security,

(ii) any document constituting evidence of title to or interest in the capital, assets, property, profits, earnings or royalties of any person or company,

(x) any document constituting evidence of a fractional undivided interest in any leasehold or real property, where the interest is part of a common enterprise for profit.

Section 35(1) of the Securities Act provides:

S. 35(1) No person or company shall trade in a security either on his own account or on behalf of any other person or company where such trade would be in the course of distribution to the public of such security until there have been filed with the Commission both a preliminary prospectus and a prospectus in respect of the offering of such security and receipts therefor obtained from the Registrar.

Section 19(1) provides that registration is not required under the Securities Act in respect of certain trades. However, those most commonly used, sections 19(1), (9.1) and (9.2), are trades in respect of a security issued by the "company". Unfortunately, there are no exemptions available to "persons".

Section 19(2) exempts registration in respect of trades in certain securities. Among those are securities issued by a prospecting syndicate where such securities are sold by the prospector or one of the prospectors who stake the claims that belong to or are subject to a declaration of trust in favour of the prospecting syndicate within the meaning of Part 6 (section 19(2)11), and securities of a prospecting syndicate within the meaning of Part 6 issued by the prospecting syndicate where the securities are sold to not more than fifty persons or companies (section 19(2)12). The scope of a prospecting syndicate as defined under the Securities Act quite severely limits its application to the oil industry.

It is interesting to note that section 34(3) of the Securities Act provides that upon issue of a receipt by the Registrar for a prospecting syndicate agreement, the requirements of the Partnership Act as to filing do not apply to the prospecting syndicate. Therefore, when acting for a potential investor, it may be necessary, in addition to searching Central Registry, to confirm whether or not a receipt has been issued in respect of $a$ prospecting syndicate agreement.

Under section $34(4)$ of the Securities Act no person or company registered for trading in securities shall trade in a security issued by a prospecting syndicate either as agent for the prospecting syndicate or as principal. This would, therefore, preclude the involvement of any brokerage houses in the sale of prospecting syndicate interests. 
Since the exemptions available in respect of registration of trades and securities traded by a partnership are not as broad as those for corporations, consideration must be given to the filing of a prospectus pursuant to section 35 of the Securities Act. The principal question in determining whether or not a prospectus must be filed is, of course, whether or not the sale of partnership interests would constitute a distribution to the public. ${ }^{10}$ In essence, a distribution of securities will not be a distribution to the public if it is to business associates, close friends or relatives of the issuer. Since the answer to this question is subjective, it must be considered in respect of each intended sale of securities to each person or company proposing to purchase a partnership interest as well as in respect of the distribution as a whole. It should also be remembered that the partnership is the issuer, and it is not clear whether the definition of persons who are not members of the public extends to the business associates, close friends or relatives of the general partner, and if the general partner is a company, to its business associates and directors and senior officers.

In addition, the North American Securities Administrators Association Guidelines of September 22, 1976 should be considered in any public issue.

\section{The Foreign Investment Review Act, S.C. $1973-4$, c. 46}

Regard must also be had to the Foreign Investment Review Act in respect of the acquisition of control of a Canadian business enterprise and of the establishment of new business in Canada. Under its provisions, a limited partnership may by definition be subject to review in respect of any proposed transaction involving acquisition of control of a Canadian business enterprise or the establishment of a new business in Canada. The Act requires that notice be given to the Foreign Investment Review Agency as follows:

S. 8(1) Every non-eligible person, and every group of persons any member of which is a
non-eligible person, that proposes to acquire control of a Canadian business enterprise
shall give notice in writing to the Agency of such proposal in such form and manner
and containing such information as is prescribed by the regulations.
S. 8(2) Every non-eligible person, and every group of persons any member of which is a
non-eligible person who proposes to establish a new business in Canada shall,
(a) if immediately before the time when a new business is proposed to be established no
other business is carried on in Canada by that person or group of persons, or
(b) if each other business is carried on in Canada by that person or group of persons
immediately before the time referred to in subparagraph (a) is a business to which
the new business would, if established, be unrelated,
give notice in writing to the Agency of such proposal in such form and manner and
containing such information as is prescribed by the regulations. (emphasis added)

Control of a Canadian business enterprise may be acquired by the acquisition of all or substantially all of the property used in carrying on the business in Canada (section $3(3)$ ). Furthermore, the acquisition of a leasehold interest in any property used in carrying on a business shall be deemed to constitute the acquisition of that property (section $3(6)(e)$ ). Guidelines have been issued in respect of the acquisition of interests in oil and gas rights which should be taken into consideration in determining whether or not the Act applies to a specific acquisition.

Unfortunately, subsection 8(2) may apply in the case of the establishment of a limited partnership where one or more limited partners were

10. See Rose, The Issuing of Shares in a Private Company Correspondence, (1963) 3 Alta. L. Rev. 109. 
non-eligible persons, even though they had contracted out their right to control or manage the business of the partnership by the partnership agreement. Unlike the test applied to corporations, there are no provisions with respect to percentages of the group which are non-eligible persons; one non-eligible person, regardless of the size of the group, will bring the group within the requirements of section 8 . Therefore, when registering a limited partnership certificate, none of the partners disclosed on the certificate should be non-eligible persons.

The provisions of subsection $8(1)$ might be avoided if the partnership is formed and acquires its property prior to the admission into the partnership of the non-eligible person. However, the subsequent acquisition of a limited partnership interest by the non-eligible person may itself be reviewable under that Act if the limited partner has a contingent right under the partnership agreement to acquire control of the business or assets of the business at a future time. Therefore, the right to amend the agreement to create an ordinary partnership should be prohibited or at least made subject to Foreign Investment Review Act approval, and the right to the return of the contribution should be restricted to cash.

The writer understands that a review of the Foreign Investment Review Act is currently being undertaken. One of the amendments which may be considered is the clarification of the position of non-eligible persons as limited partners in a limited partnership, non-operators under operating agreements and parties entitled to rights of first refusal which may accrue in the future. Hopefully, the government will amend this Act so that there would be no review of transactions involving non-eligible persons who have no right to control over or direction of the business, or who can acquire such rights only with the approval required under that Act.

The Foreign Investment Review Act provides that any transaction reviewed by the Agency may be disallowed. Likewise, any reviewable transaction not reviewed by the Agency may be rendered "nugatory" upon application by the Minister to a superior court.

4. The Gas Utilities Act, R.S.A. 1970, c. 158 and

the Public Utilities Board Act, R.S.A. 1970, c. 302

Section 24(1) of the Gas Utilities Act provides that no owner of a gas utility shall:

\section{S. 24(1)(e) issue any}

(i) of its shares or stock, or

(ii) bonds or other evidences of indebtedness, payable in more than one year from the date thereof,

unless it has first satisfied the Board that the proposed issue is to be made in accordance with the law and obtained the approval of the Board of the purposes of the issue and an order of the Board authorizing the issue, or

(f) capitalize

(i) ...

(ii) any right, franchise or privilege, in excess of the amount actually paid to the Province or any municipality as consideration therefore, exclusive of any tax or annual charge, or

(iii) any contract for consolidation, merger or lease, or

(g) without the approval of the Board,

(i) sell, lease, mortgage or otherwise dispose of or encumber its property, franchises, privileges or rights, or any part thereof, or 
(ii) . . .

and every sale, lease, mortgage, disposition, encumbrance, merger or consolidation made in contravention of this clause is void and of no effect but nothing in this clause shall be construed to prevent in any way the sale, lease or other disposition of any of the property of the owner of a gas utility in the ordinary course of his business.

Similar provisions appear under section 87(1)(3), (f) and (g) of the Public Utilities Board Act in respect of the owner of an oil pipeline. The Gas Utilities Act defines the owner of a gas utility as the owner of a gas line or related facility starting from one inch of pipe above the ground downstream to delivery to the ultimate consumer of the gas; in contrast, an oil line only acquires its status under the Public Utilities Board Act if the owner thereof has been declared to be a common carrier by the Energy Resources Conservation Board pursuant to the Oil and Gas Conservation Act, R.S.A. 1970, c. 267.

While a limited partnership interest may not be "stock" or "shares", it would be evidence of indebtedness "payable in more than one year from the date thereof", since ultimately it is repayable. It is important to note that the requirement of the Board approval is not limited to the case of public financings. Furthermore, a section $3(1)(b)$ declaration in favour of the general partner will not extend to the partnership.

Paragraphs (e) and (f) of section 24(1) of the Gas Utilities Act merely prohibit the owner of the gas utility from a range of activities. Presumably, the effect of not complying with these paragraphs is the commission of an offence under section 42,43 or 44 , with the resultant penalty under section 45 . However, section 46 raises the question of civil liability; and, while a statutory cause of action is not granted, one should consider the possibility of "nuisance" litigation arising out of an issue of partnership interests. Section $24(1)(\mathrm{g})$, however, provides that the transaction is null and void if approval is not obtained and the transaction does not fall within the ordinary course of business of the gas utility owner.

\section{THE PARTNERSHIP AGREEMENT}

The following are examples of some of the terms a limited partnership agreement might contain. They are not intended to be all-encompassing but merely provide a starting point for discussion from which an agreement might be evolved to meet a specific situation. They might be considered when reviewing an agreement for a prospective investor.

Furthermore, the Income Tax Act (Canada) should be considered in relation to specific provisions.

\section{PARTNERSHIP AGREEMENT}

THIS AGREEMENT OF LIMITED PARTNERSHIP made as of the day of , 19 by and among , incorporated

under the laws of the Province of Alberta, as general partner (the "General Partner") and those parties from time to time becoming bound hereby by executing and delivering to the General Partner a counterpart hereof (the "Limited Partners"), the General Partner and the Limited Partners collectively herein referred to as the "Partners".

NOW THEREFORE WITNESSETH that in consideration of these premises, the Parties hereto agree as follows: 
ARTICLE I

DEFINITIONS

\subsection{Definitions}

In this Agreement, unless the context otherwise requires, the following words or expressions shall have the following meanings:

(a) "Certificate" means the Certificate filed and recorded in the Central Registry under the Chattel Security Registries Act (Alberta) forming the Partnership pursuant to the Partnership Act as from time to time amended.

(b) "contribution" means the amount in cash or other property contributed to the Partnership by a Limited Partner or the General Partner in accordance with this Agreement.

Notes:

(i) If the General Partner is to make a "refundable contribution", allowance should be made for this in defining "contribution" possibly by limiting the expression "contribution" to Limited Partners.

(c) "extraordinary resolution" means a resolution passed at a meeting of Limited Partners by a majority of not less than $75 \%$ of the holders of contributions, by amount, of the Limited Partners who voted in respect of such resolution, or a resolution consented to in writing by all of the Limited Partners who would have been entitled to vote on the resolution.

(d) "gross income" means the aggregate of all income (as defined in the Income Tax Act (Canada)) to which the Partnership is entitled in its own right, from all sources, after deducting the Partnership's proportionate share of any and all lessor's royalties (including, without limitation, Crown royalties) and all gross overriding royalties.

(e) "net income" means gross income less any sums retained for Partnership purposes pursuant to paragraph 7.5 hereof.

(f) "net profits" means the profits of the Partnership, if any, resulting after making the calculations set forth in paragraphs 7.1 and 7.2 hereof, respectively.

(g) "ordinary resolution" means a resolution passed at a meeting of Limited Partners by a majority of not less than 51\% of the holders of contributions, by amount, of the Limited Partners who voted in respect of such resolution and who would have been entitled to vote on the resolution.

(h) "Partnership Agreement", "this Agreement", "this Partnership Agreement", "herein", "hereby", "hereof", "hereunder", and similar expressions mean or refer to this Agreement of Limited Partnership and any amendments thereto.

(i) "Partnership" means the Limited Partnership formed pursuant to the terms of this Partnership Agreement and under the Partnership Act.

(j) "The Partnership Act" means the Partnership Act, being Chapter 271 of the Revised Statutes of Alberta, 1970, as amended.

(k) "petroleum substances" means petroleum, natural gas and related hydrocarbons and products derived therefrom.

(l) "petroleum properties" means any lands or any interest in any lands acquired or proposed to be acquired with a view to recovering petroleum substances therefrom. 
(m) "Sharing Ratio" shall mean:

(i) in respect of all the Limited Partners,

(\%) per cent of all contributions to the Partnership,

(ii) in respect of the General Partner,

( \%) per cent of all contributions to the Partnership.

(n) "Unit" or "Unit of participation" means an amount of contribution to the Partnership as provided in paragraph 6.2 hereof.

\subsection{Headings}

The headings used throughout this Agreement are solely for the convenience of the parties and are not to be used as an aid in the interpretation of this Agreement.

\subsection{Gender}

All words herein in the make gender shall be deemed to include the female gender, corporations and partnerships, syndicates or other associations and the singular number shall include the plural number, as the case may be, whenever the context shall so require.

\section{ARTICLE II \\ THE PARTNERSHIP}

\subsection{Formation of Partnership and Name}

The parties hereto hereby agree to, and hereby do, form, in accordance with this Agreement and the Partnership Act, the Partnership under the name and style

\subsection{Certificate}

Upon request of the General Partner, each Limited Partner shall immediately execute all certificates and other documents consistent with the terms of this Agreement necessary for the General Partner to accomplish all filing, recording, publishing and other acts as may be appropriate to comply with all requirements for the formation and operation of a limited partnership in any jurisdictions where the Partnership intends to operate.

\section{Notes:}

(i) The name must be stated in the Certificate.

(ii) Central Registry does not conduct any searches of names, therefore, caution should be taken to assure that the name chosen is not the same as or similar to any other partnership or company registered or carrying on business in Alberta.

(iii) In fact, the limited partner will usually only sign the Subscription Form (Schedule "A") which contains a power of attorney in favour of the general partner.

\subsection{Effective Date}

(a) The Partnership shall be effective on the date of filing and recording in the Central Registry, the Certificate duly executed by all of the Partners, General and Limited, as required by the Partnership Act, and shall be effective in respect of the admission of a duly executed counterpart hereof to the General Partner and registration of the appropriate Notice to Amend a Certificate in accordance with the Partnership Act. 
(b) Notwithstanding anything herein contained, in respect of the rights and obligations of the Limited Partners hereunder, the terms, covenants, conditions and provisions of this Agreement shall commence and be enforceable by and binding upon a Limited Partner as between the Limited Partner and all other Partners as of and from the date of acceptance of the subscription of the Limited Partner, by the General Partner, which date shall be communicated to the Limited Partner, by notice in writing from the General Partner.

(c) The Partnership Certificate shall not be filed until the aggregate amount agreed to be contributed in cash to the capital of the Partnership by the Limited Partners is equal to the sum of $\$$

Notes:

(i) The Effective Date of formation of the Partnership is in fact established by section 51(1) of the Act. Section 64 provides that after formation of the Partnership additional limited partners may be admitted by amendment of the Certificate.

(ii) The Certificate could be registered prior to raising all or any part of the desired capitalization. However, subparagraph (c) would serve as protection for the limited partner in the case of a specific venture partnership requiring a predetermined minimum capitalization from becoming liable for his contribution by virtue of the certificate being filed prior to the minimum being raised.

(iii) If the Foreign Investment Review Act is a potential concern, subparagraph (c) may have to be deleted or modified to contemplate future additional limited partners who are non-eligible persons under that Act.

\subsection{Principal Place of Business}

The principal place of business of the Partnership shall be Calgary, Alberta or such other address or addresses as the General Partner may designate by written notice to the Limited Partners. The Partnership may maintain such other offices as the General Partner may determine, at such other address or addresses designated by the General Partner.

Notes:

(i) See Section 27(j).

\subsection{Addresses of Partners}

(a) The address of the General Partner is Such address may be changed by written notice to the Limited Partners.

(b) The addresses of the Limited Partners, respectively, are as set forth opposite their names on the Subscription Page and may be changed in accordance with the provisions of paragraph 5.8 hereof.

Notes:

(i) Section 51(2) requires that the residence addresses of the partners, general and limited, be stated in the Certificate.

\subsection{Term and Fiscal Year}

(a) Subject to earlier termination as hereinafter provided, the Partnership shall be dissolved on the 19 day of 
(b) The fiscal year of the Partnership shall be the calendar year. Notes:

(i) The term of the partnership must be stated in the Certificate.

\subsection{Qualification to do Business}

The General Partner shall cause the Partnership to qualify to do business in the Province of Alberta as a limited partnership under the applicable laws and regulations thereof. The General Partner shall cause the Partnership likewise to qualify to engage in business in other jurisdictions wherever the General Partner shall determine that it is appropriate for the Partnership to be so qualified or otherwise to be registered.

\section{ARTICLE III}

\section{PURPOSES AND POWERS OF THE PARTNERSHIP}

\subsection{Purposes of Partnership}

The Partnership is formed for the purposes of:

(a) acquiring, holding and owning petroleum properties located in Canada, howsoever granted;

(b) exploring for, drilling for, recovering, saving, storing, transporting, treating, processing and marketing petroleum substances; and

(c) developing, operating and maintaining petroleum properties. Notes:

(i) The character of the business must be stated in the Certificate.

(ii) These purposes cover a broad, on-going business, but could be restricted to a specifically defined venture such as a property farm-in.

\subsection{Powers of the Partnership}

Without limiting the generality of paragraph 3.1 hereof, the Partnership in carrying out its purposes shall have the power and authority to:

(a) borrow money, make, issue and endorse promissory notes, bills of exchange and evidences of indebtedness of all kinds, without limit as to amount, and to secure the same by mortgage, assignment pursuant to Section 82 of the Bank Act (Canada), pledge or otherwise, of all or any part of the assets and undertaking of the Partnership, including without limitation the assignment of production or proceeds or production of petroleum properties, assigning monies owing or to be owing to the Partnership and engaging in any other means of financing;

(b) purchase or otherwise acquire and to hold, exchange or otherwise dispose of any shares or interests in any firm, partnership, syndicate, company or corporation carrying on a business the same as or similar to that of the Partnership; and

(c) enter into any agreement for the management of the assets, undertakings and business of the Partnership with any party, including without restriction, the General Partner, but not so 
as to release the General Partner from any of its duties and obligations hereunder.

Notes:

(i) If public financing is intended appropriate provision should be made so as to avoid the necessity of approval of all limited partners.

(ii) Since not all jurisdictions have provisions similar to the Partnership Act (Alberta), but registration is required in each jurisdiction in which lands are located, if for any reason the partnership cannot be registered in another province, another vehicle may be incorporated in that jurisdiction by the partnership to hold those properties. However, there is the danger that the limited partner may lose the tax advantages they would otherwise have been entitled to.

(iii) Subsection (b)-in addition to the reasoning in (ii) above, permits the possibility of joint venturing with others.

(iv) Subsection (c)-permits the general partner to delegate its duties to others. A prospective investor should know the terms of any pre-arranged management contracts, in particular if any additional costs could be incurred. The general partner should be required to compensate the contractor out of the general partner's share of profits and indemnify the partners against any fees beyond its share. Costs are also an area where the partnership should be protected by the requirement that costs incurred be on a competitive bid basis wherever possible.

The technique of permitting the general partner to be manager by separate contract is used to protect the general partner from take-over (see also: paragraph 4.8(b)-Notes).

\section{ARTICLE IV \\ THE GENERAL PARTNER}

\subsection{The General Partner}

(a) The General Partner of the Partnership shall have unlimited liability for the liabilities and obligations of the Partnership.

(b) No person dealing with the Partnership shall be required to inquire into the authority of the General Partner to take any action or to make any decision on behalf or or in the name of the Partnership.

Notes:

(i) Subparagraph (b)-The provision must be read subject to any specific restriction or qualification contained in the Certificate.

\subsection{Powers of the General Partner}

The General Partner shall have full and exclusive power and authority on behalf of the Partnership to manage, control, administer and operate the business assets and affairs of the Partnership and to the extent required by law or to the extent the Partnership shall not be capable of holding its own assets, shall hold the Partnership assets for the benefit of the Partnership, and to do or cause to be done any and all acts deemed by 
the General Partner to be necessary, appropriate or incidental to the ordinary course of the business of the Partnership, including but not limited to the power and authority:

(a) To purchase or otherwise acquire leases, permits, reservations, licence and other rights and interests (or any interest therein) in connection with the exploration and development of petroleum properties, directly or indirectly, in whole or in part, whether the petroleum properties are then producing petroleum substances or not;

(b) To acquire or otherwise take control of other real or personal property which the General Partner considers necessary or appropriate to carry on and conduct the business of the Partnership as described in paragraph 3.1 hereof;

(c) To conduct geophysical, geological and other exploratory work, and to make decisions with respect to the drilling, testing, completing, reworking, plugging, and equipping of oil and gas wells in which the Partnership has an interest;

(d) To enter into farmout, farmin, pooling, unitization, joint venture and joint operating agreements and all other agreements in connection with the business of the Partnership and the operation and maintenance of petroleum properties in which the Partnership has an interest on behalf of the Partnership;

(e) To make or accept dry hole, bottom hole or other contributions of cash or property interests in connection with the drilling of wells by or on behalf of the Partnership or of wells on lands in which the Partnership may have an interest or in respect of lands held by others near or adjacent to the Partnership's lands, for the purposes of testing, proving or delineating reserves under lands held by the Partnership;

(f) To pay or not to pay on behalf of the Partnership any delay rental or deferred drilling charge or any like charge or assessment;

(g) Subject to subparagraph 4.5(a) hereof, to sell, surrender, abandon or otherwise dispose of any oil and gas interests or other assets of the Partnership;

(h) To install and operate or to cause to be installed and operated pressure maintenance and secondary recovery programs of all kinds;

(i) To employ personnel, agents and representatives with such powers and duties, upon such terms and conditions, at such places, and for such compensation as in the judgment of the General Partner may be necessary or advisable in carrying on the business of the Partnership;

(j) To enter into contracts with independent contractors for such work in respect of field operations or in any manner connected with the administration of the petroleum properties and upon such terms and conditions as in the judgment of the General Partner may be necessary or advisable in connection with the business of the Partnership;

(k) To retain or employ such legal, accounting, geological, geophysical and engineering services and advice in the conduct of the affairs of the Partnership; 
(1) To open bank accounts for the Partnership, to designate and from time to time change the signatories to such accounts, and to execute loan and credit agreements on behalf of the Partnership;

(m) To borrow money for the business of the Partnership and from time to time, without limit as to amount, to draw, make, execute and issue promissory notes and other negotiable or nonnegotiable instruments and evidence of indebtedness, and to secure the payment of the sums so borrowed and to mortgage, pledge, assign pursuant to Section 82 of the Bank Act (Canada), or assign in trust all or any part of the property of the Partnership, including, without limitation, the production and proceeds of production of the petroleum properties or to assign any money owing or to be owing to the Partnership, and to engage in any other means of financing;

(n) To generally do all things and take all steps in connection with the assets and undertaking of the Partnership which would be customarily carried out by a reasonable operator in the petroleum and natural gas industry in Canada;

(o) To enter into financing, underwriting, listing and other agreements and arrangements in connection with the financing of the Partnership and the distribution to the public of limited partnership interests in the Partnership;

(p) To invest funds not immediately required for the operations of the Partnership in securities of, and only in securities of or guaranteed by the Government of Canada, the Government of any Canadian province or a Canadian chartered bank, which securities mature not more than one year from the date of such investment;

(q) To submit the Partnership to binding arbitration in respect of any matter pertaining to the assets and undertaking of the Partnership.

Notes:

(i) The specific powers should be considered in light of the stated purposes.

(ii) The extent to which the Partnership cannot be shown as registered holder was discussed at page 173.

(iii) Subparagraph (p)-If a significant amount of cash is going to be contributed to or otherwise acquired by the Partnership some time prior to its ultimate expenditure, some provision should be made for its investment. If it is large enough or is to be applied toward purchases or operations over a period of time, the limited partner may even wish to have it administered by a trust company of bank.

(iv) Subparagraph (g)-For the reference to arbitration, see page 155.

\subsection{Qualifications of the General Partner} to do Business and Representations

(a) The General Partner hereby represents and warrants that as at the date of this Agreement it is a body corporate duly incorporated under the 
laws of the Province of Alberta and that it is and while it is the General Partner shall be duly registered to carry on business in all jurisdictions in which its activities or those of the Partnership render such registration necessary.

(b) The General Partner hereby covenants that so long as it is the general partner of the Partnership it shall maintain its corporate existence.

(c) The General Partner may discharge its duties as nominee without disclosing that it is acting as nominee, or may disclose that it is so acting as nominee, with the same authority, power and effect in either of such events for all purposes as it could do if it were in fact the owner in its own right of the Partnership assets, including the petroleum properties then held by the Partnership.

\subsection{Duties}

(a) The General Partner shall be under the duty to manage and operate the Partnership and the assets and undertaking thereof in a manner which would be considered reasonable and prudent in the petroleum and natural gas industry in Canada. The General Partner, while acting in good faith and in the best interests of the Partnership, shall not be liable to the Partnership, to any Limited Partner or to any person claiming through any limited partner for any mistake or error made in good faith by it or its agents, servants or employees while carrying out its duties as general partner and manager of the Partnership.

(b) The General Partner shall maintain, at the expense of the Partnership, complete and accurate books and records of all assets, rights and interests acquired by the Partnership, complete records of all invoices, bills, statements and other documents in relation to the business of the Partnership, and all correspondence concerning the business of the Partnership. All such books and records and all receipts, vouchers and memoranda relating thereto shall be retained for a minimum period of six (6) years, and subject to the provisions of subparagraph 5.4(a), shall be available for inspection at the General Partner's offices in the City of Calgary, by any Limited Partner during regular business hours.

(c) The General Partner shall at all times maintain the confidentiality of geophysical, geological, financial and other information and data which it may obtain through or on behalf of the Partnership and shall utilize such information and data only for the business of the Partnership.

(d) The General Partner shall cause the Limited Partnership, in calculating its income or loss for any fiscal year, to deduct the maximum capital cost allowance available to it for that year.

Notes:

(i) Subparagraph (a)-The extent to which a general partner should be excused from liability for injury caused by its negligence is somewhat subjective. Presumably it should be liable for ordinary negligence or wilful misconduct on the past or it or its servants, agents or employees.

(ii) Subparagraph (b)-See Section 27(j). The place where the books are to be kept may be varied in the Partnership Agreement. 


\subsection{Restrictions}

(a) Subject to subparagraph (b) of this paragraph, the General Partner shall not cause the Partnership to sell or otherwise dispose of all or substantially all of its assets unless such sale or disposition is approved by an extraordinary resolution. A farmout or other arrangement whereby a third party is entitled to acquire an interest in all or substantially all of the interests of the Partnership shall be deemed to be a disposition subject to the terms of this paragraph. The granting of any security for advances made to the Partnership shall be deemed not to be a disposition within the meaning of this paragraph.

(b) Neither the General Partner nor any associate or affiliate company thereof nor any partnership in which the General Partner or any such associate or affiliate company is a partner may purchase or otherwise acquire any part of the petroleum properties either from the Partnership, from any third party within a period of two years after any such abandonment or surrender without the affirmative vote of all the Limited Partners given at a meeting thereof convened to consider such proposed purchase or acquisition. For the purposes of this Agreement, the expressions "associate" and "affiliate company" shall have the meanings ascribed to them by the Securities Act (Alberta), as amended.

(c) Neither the General Partner nor any associate or affiliate company thereof nor any partnership in which the General Partner or any such associate or affiliate company is a partner may sell, farm out or otherwise dispose of any real or personal property (or any interest therein) or make loans to the Partnership without the affirmative vote of all the Limited Partners given at a meeting thereof convened to consider such transaction.

(d) The General Partner shall not be paid for providing to the Partnership any services in addition to those required of it under the terms of this Agreement unless the charges of the General Partner to the Partnership for such additional services are less than or equal to the best available competitive rates for such services from persons who are in the business of providing such services.

(e) The General Partner shall not cause the Partnership to guarantee the obligations or liabilities of or make any loans to the General Partner, or any associate or affiliate company thereof or any partnership in which the General Partner or such associate or affiliate company is a partner.

(f) The funds of the Partnership shall not be commingled with the funds of the General Partner or any associate or affiliate company thereof or any partnership in which the General Partner or such associate or affiliate company is a partner.

(g) Subject to the provisions of paragraph 4.2 hereof, the General Partner shall not have the authority or power to delegate its duties as General Partner hereunder.

Notes:

(i) Since it is probable that a general partner will be in the oil business and will likely have or is likely to acquire interests in ventures other than the Limited Partnership, the power of the general partner to deal with partnership assets should be restricted in relation to non-arm's length transactions.

However, the absolute prohibition on non-arm's length 
transactions may work to the disadvantage of the Partnership if any future financings (such as by farmout) or property exchanges should become necessary or advisable.

The requirement of unanimous consent in non-arm's length transactions may be practical in small, closely held partnerships but not in large, publicly held partnerships. However, the conflict of interest problem should be considered before substantially reducing this restriction.

The non-arm's length transactions restriction could be qualified by permitting stated transactions, or transactions based on the reports of more than one independent petroleum engineering firm (based upon fair market value or discounted cash flow? What discount rate?) or if the transaction is based upon terms more favourable than obtainable elsewhere (there will always be a problem of assessment with this exception, and, of course the question of bona fide transactions to be used for the comparison).

(ii) Subparagraph (d)-The general partner's share of profits should take into account its overhead for acting as well as some return. If the arrangement is for the share of profits to represent the return and the overhead costs to be separately recovered then the sharing ratio of the general partner should not likely be greater than $10 \%$ to $15 \%$ of net profits in the case of a production fund (see notes to paragraphs 4.6 and 7.3 ).

\subsection{Reimbursement}

(a) All expenses reasonably and necessarily incurred by the General Partner in managing and conducting the business of the Partnership, including the cost of such professional, technical, administrative and other services and advice as the General Partner shall deem necessary, shall be paid by the Partnership.

(b) The General Partner shall pay out of funds of the Partnership on hand or funds borrowed for Partnership purposes, any and all third party costs and expenses as and when the same become due.

(c) The General Partner shall be entitled to demand reimbursement from the Partnership for any and all third party costs and expenses paid or to be paid on behalf of the Partnership as and when the same become due and payable.

(d) Subject to all third party costs and expenses then due or accruing due having been paid or provision made therefore, the General Partner shall be entitled to receive from the Partnership the General Partner's overhead charge of $\%$ of the aggregate expenditures of the Partnership in acquiring, exploring, developing, maintaining, operating and abandoning petroleum properties, from and after the date of formation of the Partnership, payable at intervals of not more than once each thirty days.

\section{Notes:}

(i) This agreement contemplates that the general partner is to be paid overhead costs in addition to its share of profits. If the agreement provides separately for a share of profits and compensation for overhead costs, then the general 
partner would in effect rank ahead of the limited partners in respect of income distributions at least in respect of the overhead portion.

(ii) However, Section $58(2)$ seems to contemplate that the limited partners would rank ahead of the general partner in income distributions (see page 168).

(iii) The fact that the general partner is given a priority as to its overhead costs is not itself unenforceable. If the limited partners wished to have similar protection, the agreement might provide for payment of a specific sum before participating in the balance of profits. However, the oil industry does not always have assured returns, particularly in smaller ventures.

Furthermore, on dissolution, Section 72 would have the effect of placing the general partner's claims behind those of the limited partners.

\subsection{Limitation on Exploration Expenditures}

The General Partner shall not incur costs and expenses, inclusive of the General Partner's overhead charges in connection therewith, in excess of $\$ \_$in respect of operations classed as Canadian Exploration Expenses within the meaning of the Income Tax Act (Canada), as amended.

\section{Notes:}

(i) This provision might be included to limit the risk associated with exploration activities and could be expressed as a percentage of the total capitalization of the Partnership.

\subsection{Change of General Partner}

(a) The General Partner shall not sell, assign or otherwise dispose of its interests as the general partner in the Partnership unless such sale, assignment or disposition shall be approved by an extraordinary resolution; provided that there shall not be more than one General Partner at any time.

(b) The General Partner may be removed as general partner and manager of the Partnership and a new general partner appointed by an extraordinary resolution to that effect. Upon the payment of all amounts then due to the General Partner by virtue of paragraph 4.6, and the General Partner's contribution to the Partnership, if any, and upon appointing the succeeding general partner, the General Partner shall cease to be a general partner and manager of the Partnership.

(c) The General Partner may be replaced as general partner and manager of the Partnership and a new general partner appointed if approved by an ordinary resolution to that effect at a meeting of Limited Partners convened to consider the effect on the Partnership of the bankruptcy, dissolution or winding-up of the General Partner or the appointment of a trustee or permanent receiver of the affairs of the General Partner, provided the said meeting is called within one hundred and twenty (120) days after the occurrence of the bankruptcy, dissolution, winding-up or appointment of a trustee or permanent receiver. Upon the registration of the Notice to Amend the Certificate in accordance with the Partnership Act appointing the succeeding general partner, the General 
Partner shall cease to be the general partner and manager of the Partnership.

(d) The General Partner may be removed as general partner and manager of the Partnership and a new general partner appointed if approved by an ordinary resolution to that effect at a meeting of Limited Partners convened to consider the breach by the General Partner of the restrictions contained in subparagraphs $4.5(\mathrm{a}),(\mathrm{b}),(\mathrm{c}),(\mathrm{e}),(\mathrm{f})$ or $(\mathrm{g})$ or the breach by the General Partner of the covenants, representations and warranties contained in subparagraph 4.3(b). Upon the registration of the Notice to Amend the Certificate in accordance with the Partnership Act appointing a succeeding general partner the General Partner shall cease to be the general partner and manager of the Partnership.

(e) From and after the date of a resolution to remove the General Partner passed pursuant to subparagraph (d) of this paragraph, the General Partner shall not commit the Partnership in any manner other than in respect of expenditures to maintain and preserve the assets and undertaking of the Partnership until the succeeding general partner shall assume its duties, rights and obligations hereunder and this provision shall not be effective as against the succeeding general partner as it relates to the General Partner 80 removed.

(f) Upon the removal of the General Partner, as aforesaid, the General Partner shall do all things and shall take all steps to immediately and effectively transfer the management of the Partnership to the new general partner including the execution of all deeds, certificates, declarations and other documents whatsoever which may be necessary to effect such change and to convey all the assets of the Partnership to the succeeding general partner of the Partnership.

(g) Upon the removal of the General Partner as aforesaid, the Partnership and the Limited Partners shall release and hold harmless the General Partner from all actions, claims, costs, demands, losses, damages and expenses with respect to events which occur in relation to the Partnership after the registration of the Notice to Amend the Certificate as above provided.

(h) In the event of a change of general partner of the Partnership pursuant to this Article, the succeeding general partner of the Partnership shall prior to the registration of the Notice to Amend the Certificate execute this Agreement and shall from and after the time of registration of the Notice to Amend the Certificate, for all purposes and in all ways, assume the powers, duties and obligations of the General Partner under this Agreement and shall be subject to the terms of this Agreement, mutatis mutandis, and for the purposes of this Agreement the succeeding general partner shall thereafter be defined as the "General Partner" in the place of the General Partner 80 replaced.

\section{Notes:}

(i) Subparagraph (a)-The problem of minority interest holders' actions based on oppression should be kept in mind in fixing the majority required to pass a resolution as important as this, particularly in widely held partnerships having or potentially having power blocks.

(ii) Subparagraph (b)-If the majority required in this provision is too low, the general partner may be exposed to the 
danger of a hostile "take-over" if the Partnership proves to be lucrative.

On the other hand, if it is too high and the interests are widely held, the limited partners may never be capable of removing an incompetent general partner.

(iii) Subparagraph (c)-The time within which the action must be taken should be considered in light of the size of the partnership, the speed with which information is communicated to the limited partners and the degree of organization of the limited partners.

(iv) One should always bear in mind the likelihood of getting a quorum at a meeting, let alone sufficient votes to carry a motion.

\section{ARTICLE V \\ LIMITED PARTNERS}

\subsection{Admission of Limited Partners}

A person, corporation, partnership, syndicate or other association may become a Limited Partner in the Partnership upon:

(a) execution and delivery to the General Partner of a counterpart of this Agreement and subscription substantially in the form of Schedule " $A$ " annexed hereto, or otherwise becoming bound by the terms, covenants and conditions hereof, as a Limited Partner; and

(b) delivery of the Limited Partner's contribution or portion thereof acquired on admission to the Partnership to the General Partner; and

(c) acceptance of the person, corporation, partnership, syndicate or other association by the General Partner to become a Limited Partner, and

(d) registration of the Certificate or Notice to Amend the Certificate, as the case may be.

\subsection{Recognition}

Subject to paragraph 2.3(b) hereof, Limited Partners, whether named in the Certificate or in any Notice to Amend the Certificate shall not become Limited Partners until the time of registration of the Certificate or Notice to Amend the Certificate, as the case may be.

\subsection{Additional Limited Partners}

The General Partners may at any time and from time to time admit such additional Limited Partners as the General Partner shall in its sole discretion determine.

Notes:

(i) If the Partnership is to be restricted as to numbers or as to the time during which the general partner may admit additional limited partners it should be provided for.

(ii) This provision must be stated in the Certificate.

\subsection{Rights}

(a) A Limited Partner has the right of access to the books and records of the Partnership and has the right at his expense to have an 
examination thereof by his representative during regular business hours as provided in subparagraph 4.4(b), provided however that no Limited Partner has the right of access to any data or information of the Partnership which in the opinion of the General Partner is in the interest of the Partnership and to be kept confidential.

(b) The Limited Partners shall be entitled to and shall receive on or before March 31 in each year, a written statement from the General Partner, commencing March 31, 197_ containing audited financial statements of the Partnership for the calendar year just ended as reported on by the auditors of the Partnership, an appraisal report with respect to the assets and liabilities of the Partnership, a report respecting the properties and the undertakings of the Partnership, including the status of the exploration and development to be undertaken during the next reporting period, and a statement containing all tax reporting and other information necessary to permit that Limited Partner to claim all permissible credits, rebates or similar items, under federal or provincial legislation. In addition, the General Partner shall annually, not later than September 30, forward to each Limited Partner unaudited financial statements of the Partnership as of June 30 of that year and a report concerning the petroleum properties and the undertakings of the Partnership, including the status of the exploration and development of the petroleum properties and general information concerning the proposed exploration and development to be undertaken during the next reporting period.

(c) The Limited Partners shall be entitled to and shall receive on or before March 31 in each year, a written appraisal of the assets of the Partnership prepared as of the 31st day of December of the preceding year, commencing March 31, 19_ such appraisal being mailed to each Limited Partner. Such appraisal shall be prepared on the basis of:

(i) the net present worth of proven and probable natural gas and oil reserves as determined by an independent petroleum consultant, selected by the General Partners, employing a discount factor which such consultant deems fair and reasonable and which shall be set forth in such determination;

(ii) all proven oil and gas acreage as appraised by an independent petroleum consultant, selected by the General Partner, on such basis as such consultant deems fair and reasonable and which shall be set forth in such appraisal; and

(iii) all other assets shall be appraised by a person skilled in making the appraisal required, selected by the General Partner, on the basis of what such appraiser considers is the then fair market value and which shall be set forth in

Notes: such appraisal.

(i) Subparagraph (a)-The limited partner's right to information is protected by Section 57(a) and (b). Therefore, it is questionable whether or not an arbitrary restriction on the right to information is enforceable as a right which may be contracted out of or on which the courts will preserve in spite of contractual restrictions. 


\subsection{Restrictions}

(a) No Limited Partner shall take part in the management of the business of the Partnership or transact any business for the Partnership in his capacity as a limited partner of the Partnership.

(b) No Limited Partner shall have the right to sign for or to bind the Partnership in his capacity as a limited partner of the Partnership.

(c) Each Limited Partner hereby irrevocably waives during the term of this Agreement any rights which he may have to maintain any action for partition or sale with respect to leases held by the Partnership or any interests therein or any other interests of the Partnership in real or personal property whether corporeal or incorporeal.

(d) The Limited Partners shall at all times, both during the term of the Partnership and after its termination, maintain the confidentiality of geophysical, geological, financial and other information and data which the Limited Partner may obtain through the Partnership.

(e) During the term of the Partnership the General Partner will acquire, by the expenditure of Partnership funds, geophysical, geological and other data and information, and evaluation work will be done with respect thereto. Notwithstanding any provision of this Agreement to the contrary, no Limited Partner shall at any time either during the term of the Partnership have any right or title to any such data or information, or studies, maps, evaluations or reports derived therefrom nor, after the termination of the Partnership, the right to review the same. The General Partner shall have the exclusive right to use and exploit all of such data and information at all times for Partnership purposes exclusively.

Notes:

(i) Subparagraph (a)-In addition to creating the distinction between the general and limited partners, this provision may be useful if the Foreign Investment Review Act is amended as noted on page 176.

\subsection{Incapacity}

The Partnership shall not be dissolved by or upon the resignation, death, mental incapacity, insolvency, bankruptcy, receivership, dissolution, liquidation or winding up of any Limited Partner, and the legal representative of the Limited Partner shall be entitled to and assume all the rights and liabilities of the Limited Partner in respect of the Partnership.

\section{Notes:}

(i) See Section 67.

\subsection{Meetings}

(a) The General Partner may at any time and from time to time and shall upon a Limited Partners' request convene a meeting of Limited Partners. In the event of the General Partner failing to convene such meeting within fifteen (15) days after receipt of such Limited Partners' Request to convene such meeting, any Limited Partner may convene such meeting. Every meeting shall be held at a reasonable time and place in the City of Calgary. For the purposes of this subparagraph "Limited Partners' Request" means an instrument signed in one or more counterparts by no less than ten (10) percent of the then Limited Partners who hold in the aggregate not less than ten (10) percent participation in the Partnership requesting the General Partner to convene a meeting. 
(b) At least 30 days notice of any meeting (and not more than 60 days notice) shall be given to the Limited Partners (and to the General Partner if the meeting has been called by a Limited Partner). Such notice shall state the time when and place where the meeting is to be held and shall state briefly the general nature of the business to be transacted thereat. It shall not be necessary for any such notice to set out the terms of any resolution to be proposed or any of the provisions of this paragraph.

(c) The Limited Partners present in person or by proxy shall choose a person present to be chairman.

(d) Subject to the provisions of subparagraph 5.7(e), a quorum at any meeting of the Limited Partners shall consist of Limited Partners present in person or by proxy and representing at least the percentage of the contributions of the Limited Partners required to pass all the resolutions for which the meeting was called.

(e) If a quorum of Limited Partners shall not be present within 30 minutes from the time fixed for holding any such meeting, the meeting shall be adjourned to the date fourteen (14) days later (unless such day is a non-business day in which case it shall be adjourned to the next following business day thereafter) at the same time and place. Upon such an adjournment at least seven (7) days notice of the adjourned meeting shall be given to the Limited Partners (and to the General Partner if the meeting as adjourned had been called by a Limited Partner) and shall be of content as prescribed by subparagraph $5.7(b)$. At the adjourned meeting the Limited Partners present in person or by proxy shall form a quorum and may transact the business for which the meeting was originally convened notwithstanding that they may not represent fiftyone (51\%) percent participation in the Partnership.

(f) On any question submitted to a meeting each Limited Partner shall be entitled to cast such number of votes as will precisely reflect his contribution in the Partnership, and, except as otherwise specified in this Agreement, questions shall be decided by the affirmative vote of Limited Partners as if such resolution was an extraordinary resolution.

(g) Votes at meetings of the Limited Partners may be cast personally or by proxy. The instrument appointing a proxy shall be in writing under the hand of the appointor or his attorney duly authorized in writing, or if the appointor is a corporation, under its seal or by an officer of attorney thereof duly authorized and shall cease to be valid one year from its date. Any individual may be appointed a proxy. In the case of joint registered holders of an interest in the Partnership any one of them present in person or by proxy at the meeting may vote in the absence of the other or others; but in case more than one of them be present in person or by proxy, they shall vote together as one in respect of the unit of which they are joint registered holders.

(h) The first item of business at such meeting shall be the election of a chairman of the meeting and the chairman shall determine the validity of all instruments of proxy to be utilized at such meeting.

(i) A vote cast in accordance with the terms of an instrument of proxy shall be valid notwithstanding the previous death or insanity of the Limited Partner or revocation of the proxy or transfer of the unit in respect of which the proxy was given, provided that no intimation in writing of such death, insanity, revocation or transfer shall have been received at the place of meeting prior to the time fixed for the holding of the meeting. 
(j) In addition to the requirements, where applicable, of subparagraph 5.7(1), every instrument of proxy, whether for a specified meeting or otherwise shall as nearly as circumstances permit be in the form or to the effect as follows:

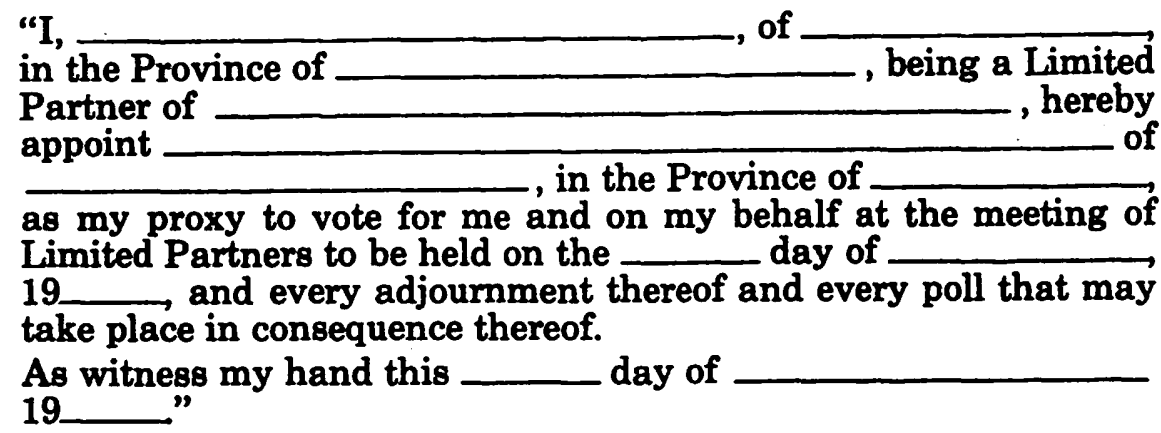

(k) Except for any solicitation by a registered holder in respect of units that are not owned beneficially by such registered holder, no person shall solicit proxies unless the person making the solicitation, concurrently with or prior thereto, delivers or sends an information circular to each Limited Partner whose proxy is solicited. For the purposes of this subparagraph "solicit" and "solicitation" include any request for a proxy whether or not accompanied by or included in a form of proxy, any form of proxy or other communication to a Limited Partner under circumstances reasonably calculated to result in the procurement, withholding or revocation of a proxy, but do not include the sending or delivery of a form of proxy to a Limited Partner in response to an unsolicited request made by him or on his behalf. Subject to the provisions of this Agreement, the information circular required hereunder shall conform, insofar as is applicable, to the form and content prescribed for information circulars by Items 1;2;3(a), (b) and (d); 6(b), (c), (d), (e) and (f); 7; 9 and 10 of Form 20 of the regulations passed under the Securities Act (Alberta). For the purposes of construing such regulations, "management" shall mean the general partner; "corporation" shall mean the Partnership; "director" shall mean a director or senior officer of the general partner, respectively; "equity share" shall mean a Limited Partner's contribution and "shareholder" shall mean Limited Partners.

(1) Where subparagraph $5.7(\mathrm{k})$ is applicable to a solicitation of proxies:

(i) the form of proxy sent to a Limited Partner by a person soliciting proxies shall indicate in boldfaced type by whom the proxy is being solicited and the form of proxy or the information circular shall state the name, address and principal occupation or employment within the preceding five years of each person soliciting proxies and shall disclose the beneficial ownership of each such person in the Partnership;

(ii) the form of proxy shall provide means whereby the Limited Partner whose proxy is solicited is afforded an opportunity to specify that his votes shall be cast by the nominee in favour of or against, in accordance with such Limited Partner's choice, each matter or group of related matters identified therein or in the information circular as intended to be acted upon;

(iii) no proxy shall confer authority to vote at any meeting other 
than the meeting specified in the notice of meeting or any adjournment thereof;

(iv) no proxy shall confer authority to vote for the appointment of any person or corporation as a general partner of the Partnership unless the proposed nominee for such appointment is named in the information circular and unless the proposed nominee is described in reasonable detail including, if applicable, the name of every person having an interest, either directly or indirectly, to the extent of not less than five (5\%) per cent in the capital of the proposed nominee, whether such named persons are Limited Partners and the names of any Limited Partners who are associates of such named persons;

(v) the information circular or form of proxy shall state that the votes represented by the proxy shall be cast and that, where the Limited Partner whose proxy is solicited specifies a choice with respect to any matter to be acted upon pursuant to clause (ii), above, the votes shall be cast in accordance with the specifications so made;

(vi) the information circular or form of proxy shall indicate in bold-faced type that the Limited Partner has the right to appoint a person to attend and act for him and on his behalf at the meeting other than the person, if any, designated in the form of proxy, and shall contain instructions as to the manner in which the Limited Partner may exercise such right; and

(vii) if the form of proxy contains a designation of a named person as proxy, means shall be provided whereby the Limited Partner may designate in a form of proxy some other person as his nominee to attend and act at the meeting.

(m) Officers and directors of the General Partner shall have the right to attend in their capacity as such at any meeting of Limited Partners and to address any such meeting on the matters properly before it, but the General Partner in its capacity as a general partner shall not have a vote at any such meeting.

(n) To the extent that the rules and procedures for the conduct of a meeting of the Limited Partners are not prescribed in this Agreement, such rules and procedures shall be determined by the meeting.

Notes:

(i) Depending upon the number of limited partners, in the Partnership, the relative holdings and how widely spread the holdings are likely to be, the "Limited Partners Request" definition might either be loosened (by eliminating or reducing the requirement of the percentage of partners or percentage of holdings) or tightened by increasing either or both.

(ii) The question of majorities will always be a concern. Under Section 55 certain matters require unanimity. However, other matters are left to the partners to decide in whatever manner they agree upon, which should be recorded in the Partnership Agreement. If all matters could be determined by a simple majority, the risk of minority oppression actions is obviously increased, particularly if the question 
to be decided will or could affect the partners' rights or revenues.

(iii) If the partnership interests are not widely held, the proxy requirements could be simplified somewhat. It may not be entirely wise to eliminate them altogether, however.

(iv) Information circulars should be drawn with the same overriding considerations as related to disclosure, and adequacy of information given as with circulars drawn in respect of corporate transactions.

\subsection{Register of Limited Partners}

(a) The General Partner shall at all times keep and maintain at its offices a register of Limited Partners which shall contain the names, addresses and participation in the Partnership of each Limited Partner. No change of address of a Limited Partner and no transfer of any interest in the Partnership shall be effective as against the Partnership until all reasonable requirements as determined by the General Partner with respect thereto have been met and until such change or transfer is entered by the General Partner in the register of Limited Partners. The names, addresses and participation in the Partnership of the Limited Partners as reflected from time to time in the said register of Limited Partners shall be conclusive as to such facts for all purposes of this Agreement.

(b) No address of a Limited Partner shall be changed on the said register of Limited Partners except by notice in writing received by the General Partner and all communications from the Limited Partners concerning the said register of Limited Partners shall be directed to the General Partner.

\subsection{Assignment of Interest}

(a) Subject to the provisions of subparagraphs $5.9(\mathrm{~b})$ to (f) hereof inclusive, and subject to all applicable securities laws, a Limited Partner may without charge assign all or any units then held by the Limited Partner to a substituted Limited Partner.

(b) The substituted Limited Partner shall, as between himself and the other Partners, be bound by the provisions of and stand in the place and stead of the assigning Limited Partner of this Agreement as of and from the date of delivery to the General Partner of a duly executed Transfer substantially in the form of Schedule "B" annexed hereto, duly executed by the assigning Limited Partner and the substituted Limited Partner (whose endorsement shall be guaranteed by a Canadian chartered bank, a Canadian trust company, a foreign bank or trust company having a Canadian correspondent, a member of the Investment Dealers Association of Canada, or a member of any recognized Canadian Stock Exchange) and shall be accompanied by duly endorsed certificates, if any, issued by the Partnership which represent each unit being assigned.

(c) No assignment of any unit by a Limited Partner shall be recognized or entered in the said register of Limited Partners, unless such assignment is a whole unit or any integral multiple thereof.

(d) No assignment of any unit is effective unless the assignee agrees to be bound as a Limited Partner of the Partnership by the terms of this Agreement and executes a transfer form substantially in the form annexed as Schedule "B".

(e) If an assignor of a unit is a firm or a corporation, or purports to 
assign such unit in any representative capacity, or if an assignment results from the death, mental incapacity or bankruptcy of a Limited Partner or is otherwise involuntary, the assignor or his legal representative shall furnish to the General Partner such documents, certificates, assurances, court orders and other materials as the General Partner may reasonably require to effect the said assignment.

(f) The General Partner shall from time to time as soon as is practical after receiving a transfer duly executed by the Assignor and agreement to be bound by the terms hereof duly executed by the Assignee, in respect of any unit, file any Notice to Amend the Certificate at the Central Registry for the Province of Alberta and such other instruments or documents at such other places as in the opinion of counsel to the Partnership are necessary to reflect the changes in membership of the Partnership as such changes occur and shall notify the substituted Limited Partner in writing at the date of registration of such Notice to Amend the Certificate.

(g) The substituted Limited Partner, upon registration of the Notice to Amend the Certificate in respect of his being substituted as a Limited Partner shal become a Limited Partner and shall have all of the rights and liabilities of the assigning of the unit or units acquired by him hereunder (including without limitation the right to assign his interest in the Partnership in accordance herewith) and the assignor of such unit or units shall thereupon cease to be a Limited Partner, PROVIDED however, the assignor shall remain liable for any and all matters arising while he was a Limited Partner.

Notes:

(i) Subparagraph (b)-See Section 65(3) and Section 65(5).

(ii) Subsection (f)-See Section 65(5), Section 69(3).

(iii) Subparagraph (g)-See Section 65(5). This subparagraph is the statement of when the limited partner becomes a limited partner while subparagraph (b) makes the agreement binding upon the assignee as of and from the date of execution and delivery of this Agreement to be bound by the Partnership Agreement.

(iv) Subparagraph (g)-See Section 65(4)(b). To avoid the necessity of a limited partner approving a substituted limited partner, the assignor must be given the right to assign his interest and this disclosed in the certificate.

\section{ARTICLE VI \\ CONTRIBUTIONS}

\subsection{Contribution of General Partner}

In addition to the contribution of its unlimited liability as the only General Partner, the General Partner shall make a refundable contribution to the Partnership of cash up to $\$$ (Canadian funds).

Notes:

(i) Section 51(2)(e) requires that this fact and the actual amount of the contribution be disclosed in the Certificate.

(ii) The fact that the contribution is refundable is likely of no consequence under the Partnership Act because of the general partner's unlimited liability. However, it may prove to be a deficiency in the eyes of some Securities 
Commissions. Ontario and possibly Alberta appear to be moving toward the requirement of a $10 \%$ or better cash or property contribution to the Partnership which would not be refundable.

\subsection{Contributions of Limited Partners}

Each Limited Partner shall severally make a cash contribution to the Partnership capital in Canadian funds in the amount which is shown opposite his name on the signature page of this Agreement. No Limited Partner shall be entitled to interest on the amount of his contribution to the Partnership.

Notes:

(i) Section $51(2)(e)$ requires that the amount of each contribution be disclosed in the Certificate.

(ii) Contributions could be in cash or property. See Section 54(1).

(iii) For a contribution payable over certain times or on conditions an alternate form may be:

The Limited Partners hereby agree and obligate themselves, severally, to contribute and to pay in cash the contributions to Partnership capital set forth opposite their respective names on the attached Schedule 'A'. All contributions to Partnership capital shall be payable in Canadian funds at such times as are set out in Schedule ' $A$ ' hereto.

\subsection{Liability for Further Assessment}

\section{on Limited Partners}

The liability of each Limited Partner for the debts and losses of the Partnership is limited to the amount of his contribution to the Partnership plus his pro rata share of the undistributed income of the Partnership. A Limited Partner shall have no further personal liability for such debts or losses and following the delivery of his contribution to the Partnership, he shall not be subject to, or be liable for, any further calls or assessments or further contributions to the Partnership.

Notes:

(i) If there are to be future calls, this fact must be provided for and indicated in the Certificate (Section 52(2)(f)).

(ii) Since future calls cannot be unlimited without defeating the purpose of the limited partnership concept, the promoter will have to make a very accurate assessment of the Partnership's capital requirements. Overestimating may result in a reduction in the limited partner's ability to maximize his per dollar tax relief. Underestimating may result in capital shortages and loss of or damage to the viability of the project.

(iii) Overestimating capital requirements can, of course, carry the risk of discouraging investment or placing a minimum requirement beyond the ability of the selling agents to meet, which may make paragraph 2.3(c) operative, or in the case of a public offering may result in a failure of the issue. If the financing objective is attained, excess capital could of course be returned as a distribution.

(iv) Underestimating capital requirements, on the other hand, could place considerable hardship on the Partnership, 
particularly if it is a "closed-end" fund and the limited partners fail to agree to admit additional limited partners (see Section 55(f)) and the Partnership properties have insufficient loan value to support debt financing or debt financing is not permitted.

(v) To avoid the problem of having a contribution declared void for uncertainty, the amount must be ascertainable either at the time of making the contract or by reference to facts known at the time of the contract. Therefore, caution should be exercised in providing for a contribution the maximum amount of which is unknown at the time of entering into the Partnership Agreement. One such situation could be the provision of certain percentage overrun on a specified contribution. A sum certain, payable on the happening of an event would not be uncertain even though the event may never happen (see Section 62(1)(b)).

\subsection{Right to Return of Contribution}

No Limited Partner shall be entitled to a return of his contribution until the dissolution of the Partnership.

Notes:

(i) See Section 61(1).

(ii) This must be stated in the Certificate if no time for termination is stated in the Certificate (and the Agreement) to avoid the consequences of Section 61(2)(c). This item should be stated in the Certificate in any event by virtue of Section 51(2)(g).

(iii) An alternate form might provide for withdrawal, for example:

To the extent that the Partnership shall have paid all its liabilities then due or accruing due or adequate provision has been made therefor, (whether current or long term liabilities but excluding liabilities to the General Partner and to Limited Partners on account of their contributions) and subject to the consent of all the other Limited Partners, at any time and from time to time after 19 a Limited Partner may request

the return of all or any part of his contribution and the General Partner shall pay and deliver the same to him in cash within thirty days of registration of the Notice to Amend the Certificate reflecting such return of the Limited Partner's contribution.

The advisability of withdrawals depends, of course, on the ability of the Partnership to function without the returned capital.

(iv) Withdrawal provisions might also require the consent of some percentage of the limited partners less than $100 \%$. However, the usual form is not to permit any returns of capital while the business is on-going.

\subsection{Distributions on Dissolution}

(a) Upon dissolution of the Partnership, but after provision has been made for the payment of all sums owing to creditors of the Partnership, other than the Partners, the Partners shall be entitled to a return of the income and capital of the Partnership as follows: 
(i) Firstly, to the Limited Partners in respect of all sums owing to them other than as provided in subparagraphs (ii), (iv) and (vii) of this paragraph;

(ii) Secondly, to the Limited Partners in respect of their respective shares of the net profits accrued to the date of distribution;

(iii) Thirdly, to the General Partner in respect of its share of the net profits accrued to the date of distribution;

(iv) Fourthly, to the Limited Partners the amount of their respective contributions;

(v) Fifthly, to the General Partner, the amount of its contribution to the extent the same shall not have been previously refunded;

(vi) Sixthly, to the General Partner in respect of all sums owing to it other than as provided in subparagraphs (iii), (v) and (vii) of this paragraph;

(vii) Seventhly, to the Limited Partners and the General Partner to the extent of their respective sharing ratios as determined pursuant to subparagraphs 7.1 and 7.2 , respectively, in the undistributed capital of the Partnership then remaining.

(b) Distributions made hereunder shall be made to the extent of funds remaining for distribution as soon as practicable after dissolution.

\section{ARTICLE VII}

\section{PARTICIPATION IN PROFITS AND LOSSES}

\subsection{Limited Partners' Share of Profits,} Losses and Deductions

Except as otherwise provided herein, each Limited Partner shall be entitled to share in and shall bear (as the case may be):

(a) gross income, less

(b) any and all losses, expenses, deductions, liens, charges, encumbrances and burdens of every nature whatsoever arising out of the conduct of the Partnership business or attaching to the petroleum properties and any other items and allocable to the Limited Partners under any and all applicable taxing legislation, and less

(c) any sums retained pursuant to paragraph 7.5 hereof, as determined by the General Partner semi-annually on June 30 and December 31, commencing as of and from the time of registration of the Certificate, out of or attributable to the Sharing Ratio of the Limited Partners in the proportion that the aggregate contribution of the Limited Partner bears to the aggregate contributions of all the Limited Partners.

\subsection{General Partner's Share of Profits,}

\section{Losses and Deductions}

Except as otherwise provided herein, the General Partner shall be entitled to share in and shall bear (as the case may be):

(a) gross income, less

(b) any and all losses, expenses, deductions, liens, charges, encumbrances and burdens of every nature whatsoever arising out of the conduct of the Partnership business or attaching to the petroleum properties and any other items and allocable to the General Partner under any and all applicable taxing legislation, and less 
(c) any sums retained pursuant to paragraph 7.5 hereof;

as determined by the General Partner semi-annually on June 30 and December 31, commencing as of and from the time of registration of the Certificate, out of or attributable to the Sharing Ratio of the General Partner.

Notes:

(i) Depending upon the size of the partnership, it may be advisable to have quarterly determinations of net income and losses, etc. So long as distributions are not made too frequently, there should be little difficulty in reconciling profits or losses at the end of the year.

\subsection{Distributions to Partners}

(a) The Limited Partners and the General Partner shall be entitled to receive their respective shares of the net profits of the Partnership available for distribution (if any) annually on December 31, commencing in the year of registration of the Certificate.

Notes:

(i) The Act appears to contemplate distributions of profits to the Limited Partners in priority to the general partner, but the wording is permissive rather than obligatory (see Notes to Section 58(2) on page 168). This Agreement provides for sharing pari passu after payment of the general partner's overhead charges but could provide for a priority of some stated amount before the general partner would participate in the profits.

\subsection{Adjustment}

(a) In the event that the share of profits of any partner, as disclosed by the Partnership's auditors in their report given in accordance with subparagraph 5.4(b) hereof shall be at variance with his share of profits as determined by the General Partner in accordance with paragraph 7.1 or 7.2 hereof then the said auditors' findings shall be deemed to be correct and binding upon all Partners and any necessary adjustments to such Partner's share of profits shall be made by payment to or by the Partner as the case may be.

(b) In the event of an adjustment requiring payment by the Partner to the Partnership, there shall be hereby granted and created a lien in favour of the Partnership on any and all sums from time to time due and owing by the Partnership to the Partner to the extent of such sums owed to it at the prime commercial lending rate from time to time charged by the Bank plus two (2\%) per cent compounded semiannually and calculated from and after the date of the Notice of Adjustment given pursuant to subparagraph (c) of this paragraph until the adjusted sum shall be fully paid.

(c) The General Partner shall within seven (7) days after receipt of the auditors' report as contemplated by subparagraph 5.4(b) hereof, in writing advise any and all Partners in respect of whose share of profits an adjustment is to be made, the amount of the adjustment, accompanied by a cheque representing any sum payable to the Partner or a request for repayment in respect of any sum payable by the Partner. 
7.5 Calculation of Net Income

(a) The General Partner may, from time to time retain all or any portion of the gross income to meet Partnership obligations in connection with its assets and undertakings and to otherwise carry out the purposes of the Partnership and exercise the powers of the General Partner in that regard.

Notes:

(i) Without this right the Partnership could face serious financing problems. However, the General Partner could effectively prevent the limited partners from receiving any income. The result may produce a hardship on a limited partner who has borrowed to purchase his interest and expects to repay the loan out of profits.

\subsection{Accounting}

All financial aspects of the business of the Partnership shall be accounted for in accordance with generally accepted accounting principles, consistently applied.

\section{ARTICLE VIII}

\section{AMENDMENT}

\subsection{Amendments Generally}

Subject to the provisions of this Article VIII, this Agreement may be amended by an ordinary resolution approving the amendment.

\subsection{Limitations on Amendments}

(a) Paragraphs 4.6 and 4.8 may not be amended, except with the consent of the General Partner and an ordinary resolution to that effect approving the amendment.

(b) Article II, subparagraph 4.5(a) and (b) and paragraph 10.1 may only be amended by an extraordinary resolution to that effect approving that amendment.

(c) No amendment shall be made to this Agreement which would have the effect of:

(i) reducing the interest in the Partnership of any Limited Partner,

(ii) changing the liability of any Limited Partner,

(iii) allowing any Limited Partner to exercise control of the business of the Partnership,

(iv) changing the Partnership from a limited partnership to a general partnership, or

(v) amending this Article VIII.

Notes:

(i) Clause 4.8(c)(iv) might be qualified to permit change to an ordinary partnership provided that the provisions of the Foreign Investment Review Act (Canada) are first com. plied with, if applicable.

\subsection{Errors}

By written notice to the Limited Partners, the General Partner may unilaterally effect any amendment to this Agreement which is a 
correction or a manifest error or which does not affect the rights or obligations of any partner.

\section{ARTICLE IX}

\section{POWER OF ATTORNEY}

\subsection{Power of Attorney}

Each Limited Partner hereby irrevocably makes, constitutes and appoints the General Partner, and any successor to the General Partner under the terms of this Agreement, as his true and lawful attorney and agent, with full power and authority in his name, place and stead to do all of the following, namely:

(a) execute, swear to, acknowledge, deliver, file and record in the appropriate public offices all certificates, Notices to Amend a Certificate, Notice to Cancel a Certificate and other instruments which the General Partner deems appropriate or necessary to qualify, or to continue the qualification of, the Partnership as a limited partnership in the jurisdictions in which the Partnership may conduct its business; or reflecting any amendment, change or modification of the Partnership in accordance with the terms of this agreement; all conveyances and other instruments or documents which the General Partner deems appropriate to reflect the dissolution and liquidation of the Partnership pursuant to the terms of this Agreement; and all instruments relating to the admission of additional or subsequent Limited Partners;

(b) execute and file with any government body any documents which might be filed or which might be required to be filed in connection with the business of the Partnership.

The foregoing power of attorney is hereby declared by the Limited Partners to be an irrevocable power coupled with an interest, and it shall survive the death of Limited Partners and shall extend to the heirs, executors, administrators and assigns of the Limited Partners. Each Limited Partner hereby agrees to be bound by any representation made by the General Partner and any successor thereto, while acting in good faith pursuant to the within power of attorney, and each Limited Partner hereby waives any and all defences which may be available to him, to contest, negate or disaffirm the action of the General Partner and any successor thereto taken in good faith in accordance with the terms of the within power of attorney.

Notes:

(i) Section 77(1) contemplates a special power of attorney to sign documents required under Part 2 of the Act. The power may be granted by a general or limited partner to any person.

(ii) Section 77(2) requires that the power of attorney be filed in Central Registry and recorded with the document or one of the documents executed in the exercise of the special authority. Usually it will be repeated in the subscription which is executed by the limited partner (see Schedule " $A$ " to the Agreement at page 206. 
ARTICLE X

\section{DISSOLUTION AND LIQUIDATION}

\subsection{Dissolution}

The Partnership shall be dissolved upon the occurrence of any of the following events, namely:

(a) The bankruptcy, dissolution or winding-up of the General Partner, during the term hereof, unless the General Partner is replaced as provided by subparagraph 4.7 (c);

(b) An extraordinary resolution approving the dissolution of the Partnership;

(c) The declaration by the General Partner of the dissolution of the Partnership following two consecutive fiscal years of insolvency of the Partnership;

(d) The expiration of the term of this Agreement as provided in subparagraph 2.6(a).

Notes:

(i) The Limited Partner also has the right to have the Court dissolve the Partnership (see Section 57(c)).

\subsection{Receiver}

The General Partner shall serve as the receiver of the Partnership charged with the responsibility of liquidating the Partnership upon dissolution. If the General Partner is unable or unwilling to act in such capacity, the Limited Partners shall appoint some other appropriate person or party to act as the receiver of the Partnership. The receiver shall proceed diligently to wind up the affairs of the Partnership and to distribute the net proceeds from the sale of the assets thereof. During the course of such liquidation the receiver shall operate the properties and undertaking of the Partnership and in doing so shall be vested with all the powers and authority of the General Partner in relation to the Partnership under the terms of this Agreement. The receiver shall be paid his reasonable fees and disbursements incurred in carrying out his duties as such.

Notes:

(i) This, of course, follows from Sections 41 and 63.

\section{ARTICLE XI \\ MISCELLANEOUS}

\subsection{Notices}

All notices required or permitted to be given hereunder shall be sufficiently given if in writing, mailed by ordinary mail, addressed in the case of the General Partner to its address indicated in subparagraph 2.5(a), and in the case of each Limited Partner to his address indicated on the register of Limited Partners as kept by the General Partner. The General Partner may from time to time change its address for the purpose of this Agreement in the manner prescribed for the change of address of the Partnership in subparagraph 2.5(a) above and any Limited Partner may from time to time change his address for the purpose of this Agreement in the manner prescribed in subparagraph 5.8(a). Any notice 
mailed as aforesaid shall be deemed to be given three (3) days following the date on which it was mailed.

\subsection{Provisions Severable}

Every provision of this Agreement is intended to be severable. If any term or provision hereof is illegal or invalid for any reason whatsoever, such illegality or invalidity shall not affect the validity of the remainder of this Agreement.

\subsection{Counterparts}

This Agreement may be executed by the parties hereto or by their respective attormeys on their behalf in any number of counterparts with the same effect as if the parties hereto had all signed the same document. All counterparts of this Agreement shall be construed together and shall constitute one instrument.

\subsection{Time}

Time is of the essence of this Agreement.

\subsection{Proper Law}

This Agreement shall be governed by and construed in accordance with the laws of the Province of Alberta.

\subsection{Successors and Assigns}

This Agreement shall enure to the benefit of and be binding upon the parties hereto and their respective heirs, executors, administrators, successors and assigns.

IN WITNESS WHEREOF the parties hereto have executed this Agreement as of the day and year first above written.

General Partner:

Per.

Per.

Name and Address
Limited Partners (as listed below) by their attorney:

Per.

Per. 
This is Schedule "A" to that

Limited Partnership Agreement dated

19 providing for the formation of

\section{SUBSCRIPTION FORM}

TO:

The undersigned hereby subscribes for units ( $\$$ for each

each unit) in (the "Limited Partnership")

(as described in the prospectus dated 19 receipt of which is hereby acknowledged) (or: described in that Limited Partnership Agreement, a copy of which has been delivered to me).

A cheque in the said amount, payable to and this subscription form are hereby delivered in accordance with the provisions of the said Limited Partnership Agreement. The Undersigned acknowledges that participation in the Limited Partnership is subject to the acceptance of this subscription by the General Partner and to certain other conditions as set forth in the said Limited Partnership Agreement.

The acceptance of this subscription shall be effective upon the mailing of a written confirmation thereof to the undersigned at the address indicated below.

The undersigned hereby represents that if an individual, he has attained his age of majority.

It is understood that the within subscription and all enclosures contained herewith shall be returned to the undersigned at the address indicated below on or before 19 if the within subscription is not accepted by the General Partner on or before 19

The undersigned hereby irrevocably makes, constitutes and appoints and any successor thereto by amalgamation, merger or reorganization as his true and lawful attorney and agent, with full power and authority in his name, place and stead and for his use and benefit to do the following, namely:

(i) execute the Limited

Partnership Agreement dated the day of

A.D. $19 \longrightarrow$ or a counterpart thereof, so that the undersigned shall lawfully bound as a Limited Partner and entitled to all rights as such under the terms of that Limited Partnership Agreement; 
(ii) insert on the signature page of the

Limited Partnership Agreement or a counterpart thereof the address of the undersigned and the amount of the subscription for Limited Partnership Interests of the undersigned that are accepted by the General Partner and the date of that acceptance.

The power of attorney hereby granted shall be deemed to be coupled with an interest and shall be irrevocable and shall survive the death of the undersigned.

DATED at in the Province of this day of 19.

(Seal)

(Witness)

(Signature)

(Name)

(Residence Address)

(Social Insurance Number)

This is Schedule "B" to that

Limited Partnership Agreement dated

19 providing for the formation of

\section{TRANSFER OF LIMITED PARTNERSHIP INTEREST}

I, the undersigned, a Limited Partner of

(hereinafter called the "Limited Partnership") in consideration of the sum of One (\$1.00) Dollar, and other good and valuable consideration (receipt is hereby acknowledged) hereby transfer, assign and sell to

\section{(Name of Transferee)}

(Residence Address)

(hereinafter called the "Transferee") my entire right, title and interest. as a Limited Partner in the Limited Partnership to the extent of $\$$ contribution to the Limited Partnership (including without limitation the right to assign all 
or any part of the interest hereby assigned in accordance with the Limited Partnership Agreement relating to the Limited Partnership) and I hereby agree to execute or furnish any documents and to perform any other act as the General Partner may reasonably require to properly and legally effect a valid transfer of Limited Partnership Interests to the aforesaid extent or to preserve the liability status of the Limited Partnership on the completion and registration of this transfer. that:

The undersigned hereby represents and warrants to the Transferee

(a) the undersigned has not and the undersigned shall not enter into any assignment, mortgage, pledge, charge or encumbrance in respect of the interests hereby assigned and that the undersigned hereby indemnifies the Transferee from and against any claim that may be brought by any person, firm or corporation in respect of the interest hereby assigned, made through or by the undersigned;

(b) there are no liabilities attaching to the interest hereby assigned nor any other matter which is required to be disclosed in the Certificate or any Notice to Amend the Certificate other than those disclosed thereon at the date hereof; and

(c) the undersigned is unaware of any matter which may arise in the future that would be required to be disclosed in the Certificate or any Notice to Amend the Certificate.

Dated this day of

A.D. 19

(Witness)

(Signature of Limited Partner)

\section{(Residence Address)}

The above named Transferee hereby accepts the within transfer and agrees to be bound, as a party to, and as a Limited Partner in the

Limited Partnership, by the terms of the

Limited Partnership Agreement dated the

A.D. 19 as from time to time amended.

day of

The Transferee hereby irrevocably makes, constitutes and appoints and any successor thereto by amalgamation, merger or reorganization as his true and lawful attorney and agent, with full power and authority in his name, place and stead and for his use and benefit to do the following, namely:

(i) execute the Limited

Partnership Agreement dated the day of

A.D. $19 \longrightarrow$ as from time to time amended, or a counterpart thereof, so that the undersigned shall be lawfully bound as a Limited Partner and entitled to all rights as such under the terms of that Agreement; 
(ii) insert on the signature page of the

Limited Partnership Agreement, as from time to time amended, or a counterpart thereof; the address of the undersigned and the amount of the contribution represented by the Limited Partnership interest herein transferred to the undersigned, as indicated below, and the date of the registration of this transfer.

The power of attorney hereby granted shall be deemed to be coupled with an interest and shall be irrevocable and shall survive the death of the undersigned.

Dated this day of

A.D. 19

(Witness)

(Signature of Transferee)

(Seal)

(Social Insurance Number

of Transferee)

NOTE:

1. The signature of the Limited Partner transferring the within Limited Partnership Interest must be guaranteed by a Canadian Chartered Bank, Canadian trust company, foreign bank or trust company having a Canadian correspondent, member of the Investment Dealers Association of Canada, or member of any recognized Canadian Stock Exchange.

2. A transfer of a Limited Partnership Interest may have income tax implications as between the transferor and the transferee with respect to the allocation of certain costs and expenses incurred by the Limited Partnership.

\section{General Comments}

The above limited partnership agreement does not contemplate more than one general partner. If the situation requires more than one general partner, specific provisions would have to be made for the manner in which the business would be conducted and by whom. This would necessarily require provision for successors if the operating general partner ceased to hold its status as general partner and consideration of the non-operating general partner's right to challenge the operating general partner.

Limitations should be placed upon the numbers of general partners there may be at any one time. This would likely be best controlled by prohibiting partial assignments of the interest of the general partner.

Many of the provisions of the above example contemplate widely held interests. For example, the voting in some cases requires $75 \%$, and only $51 \%$ in others. If the group is small, higher percentages may be required.

\section{LIMITED PARTNERSHIPS, JOINT VENTURES AND OPERATING AGREEMENTS}

As is now evident, limited partnerships in Alberta are governed by formal rules set out by statute, equity and the common law. However, the relationships between parties under joint venture agreements and operating agreements are considerably less structured. Traditionally, the 
operating, agreement, as known in Alberta, has a fairly widely held connotation. However, the joint venture arrangement is considerably less clearly defined.

The limited partnership concept provides for the holding of property by a recognized entity in which the limited partners have no direct interest in the assets, although by virtue of the Income Tax Act (Canada) they are deemed to have direct ownership in the assets.

The operating agreement generally connotes direct ownership by a number of parties who are usually tenants in common in the same properties. One of them is selected to operate the properties subject to certain controls upon that party by the non-operators. All parties are subject to either contributing their share of the costs of an approved program or suffering the withholding of revenues until the obligation is met, either with interest or some predetermined penalty.

The joint venture may consist of the pooling of a number of properties and financial resources for the development of a common venture either through a corporate vehicle or by contractual arrangement between the parties. In the case of the joint venture employing the corporate vehicle, properties and cash will be conveyed to the joint venture company in exchange for shares or other securities establishing the participating interest of the contributor. In the case of contractual joint venture, properties and cash are usually committed to the joint venture and held in trust by one or more parties for the benefit of all. Any or all parties may provide services in addition to cash and property.

Generally, parties to an operating agreement contribute to the costs and expenses of the joint properties and receive proceeds out of the sale of production in relation to their working interests. In the limited partnership, the limited partners are normally entitled to a share in some portion of the net revenue in relation to their contribution to the partnership. The general partner may or may not have made a contribution to the partnership in the form of cash or property, but will usually receive some share of the profits for his efforts in administering the partnership properties. This share is usually subjective and varies from partnership to partnership. In the case of the joint venture, the shares of the joint venturers in profits and expenses may or may not be related to the value of their contribution to the joint venture. Furthermore, the joint venturers may, as between themselves, allocate income, expenses and tax deductions, probably. more so than would be the case in the partnership or operating agreement.

In many respects, the joint venture can be likened to an ordinary partnership with a more detailed scheme of rights and interests, but with the exception that in a contractual joint venture the parties agree that they are not a partnership. 